IZA DP No. 5421

Evolution of the Chinese Rural-Urban Migrant

Labor Market from 2002 to 2007

Zhaopeng Qu

Zhong Zhao

January 2011 


\title{
Evolution of the Chinese Rural-Urban Migrant Labor Market from 2002 to 2007
}

\author{
Zhaopeng Qu \\ Nanjing University
}

Zhong Zhao

Renmin University of China

and IZA

\section{Discussion Paper No. 5421 \\ January 2011}

\author{
IZA
}

P.O. Box 7240

53072 Bonn

Germany

Phone: +49-228-3894-0

Fax: +49-228-3894-180

E-mail: iza@iza.org

Any opinions expressed here are those of the author(s) and not those of IZA. Research published in this series may include views on policy, but the institute itself takes no institutional policy positions.

The Institute for the Study of Labor (IZA) in Bonn is a local and virtual international research center and a place of communication between science, politics and business. IZA is an independent nonprofit organization supported by Deutsche Post Foundation. The center is associated with the University of Bonn and offers a stimulating research environment through its international network, workshops and conferences, data service, project support, research visits and doctoral program. IZA engages in (i) original and internationally competitive research in all fields of labor economics, (ii) development of policy concepts, and (iii) dissemination of research results and concepts to the interested public.

IZA Discussion Papers often represent preliminary work and are circulated to encourage discussion. Citation of such a paper should account for its provisional character. A revised version may be available directly from the author. 
IZA Discussion Paper No. 5421

January 2011

\section{ABSTRACT}

\section{Evolution of the Chinese Rural-Urban Migrant Labor Market from 2002 to $2007^{*}$}

The paper studies the dynamic change of the migrant labor market in China from 2002 to 2007 using two comparable data sets. Our focus is on the rural-urban migration decision, the wage structure of migrants, the urban labor market segmentation between migrants and urban natives, and the changes of these aspects from 2002 to 2007 . We find that prior migration experience is a key factor for the migration decision of rural household members, and its importance keeps increasing from 2002 to 2007. Our results show that there is a significant increase in wages among both migrants and urban natives over this 5-year period, but migrants have enjoyed faster wage growth, and most of the increase of wages among migrants can be attributed to the increase of returns to their characteristics. We also find evidence suggesting convergence of urban labor markets for migrants and for urban natives during this 5-year period.

JEL Classification: J21, J61, O15

Keywords: rural-urban migration, labor market, wage structure, migration decision, segmentation, China

Corresponding author:

Zhong Zhao

School of Labor and Human Resources

Renmin University of China

59 Zhongguancun Ave

Beijing 100872

China

E-mail: mr.zhong.zhao@gmail.com

\footnotetext{
* We would like to acknowledge helpful comments from Xin Meng, Shi Li, and participants in the 1st CIER/IZA Annual Workshop: Research in Labor Economics in 2009 and the 2009 International Symposium on Contemporary Labor Economics at Xiamen University. The China Household Income Project (CHIP) data set used in this paper is provided by Research Center for Income Distribution and Poverty at Beijing Normal University. Collection of the Rural Urban Migration in China (RUMIC) data used in this paper is financed by IZA, ARC/AusAid, the Ford Foundation, and the Ministry of Labor and Social Security of China. Zhong Zhao is supported by the Fundamental Research Funds for the Central Universities and by the Research Funds of Renmin University of China under the project entitled "Labor Market Behavior of the Chinese Rural-Urban Migrants" (project no. 10XNJ016). Zhaopeng Qu is supported by the Funds of Humanities and Social Science of Ministry of Education in China (10YJC790209), and the Young Scholar Research Funds of Business School, Nanjing University. We are responsible for all views and the remaining errors in this paper.
} 


\section{Introduction}

Along with economic reform and social transition in China during the past 30 years, the Chinese labor market has undergone tremendous change. Since the beginning of economic reform in China in 1978, and especially since 1988, rural-urban migration in China has become an important social and economic phenomenon. More and more of the rural population has joined in the migration flow to find better opportunities in the relatively developed urban areas and coastal areas. According to the National Bureau of Statistics of China (NBS), there were around 140 million rural migrants in China in $2008,{ }^{1}$ which is probably the largest domestic migration flow in human history (Cai, 2008).

The rural-urban migrants (hereafter we refer to them simply as "migrants") have become the main labor force in the Chinese manufacturing sector, and are one of the major factors behind China's rapid economic growth. ${ }^{2}$ Many economists are wondering whether the rapid growth in China is sustainable, not only because the demand in international markets is shrinking, but also because the cost of production is increasing, especially the labor cost, on account of the rise in the migrants' wages. The recent global economic downturn is exacerbating this concern, but actually the migrant labor market was gradually changing even before the crisis (Cai, 2008).

While there are many studies of the Chinese labor market and rural-urban migration in China, most of them concentrate on three aspects. The first strand of studies is on the transition of the urban native labor market during the reform period, and includes contributions by such as Knight and Song (2003), Appleton, Song, and Xia (2005), and Dong and Xu (2009). The second strand of research is on the labor market segmentation between urban natives and migrants in wages, social welfare, and other aspects, e.g., Meng and Zhang (2001), Knight and Yueh (2008), Demurger, Gurgand, Li, and Yue (2009), and Deng and $\mathrm{Li}$ (2010). The last strand of the literature is focused on the rural-urban migration decision, and includes Zhao (2001, 2003) and Zhu (2002), among many others. Zhao (2005) provides a review of the Chinese rural-urban migration literature.

Many people have supposed that there have been many changes in the rural-urban migration population in China in the past decade, but due to the scarcity of data, there are few studies on the dynamics of the migrating

\footnotetext{
${ }^{1}$ See National Bureau of Statistics (2009).

${ }^{2}$ In China, the official household registration system (the hukou system) separates the Chinese population into rural population (with a rural hukou) and urban population (with an urban hukou). Under this system, an individual also has an official domicile - city or village. If an individual lives in her domicile, she has a local hukou; otherwise, she has a nonlocal hukou. The rural-urban migrants are the people who have a rural hukou but are working in urban areas. They may or may not have a local hukou. The urban natives are the people with a local urban hukou.
} 
population and the migrant labor market. $^{3}$ Since the urban natives and migrants are still segmented in the labor market, the migrant labor market may have its own characteristics, and also, because of the increasing importance of the migrants in Chinese society, knowledge of the evolution of the migrant labor market is crucial for grasping the whole story behind the Chinese economic miracle.

In this paper, we investigate the change in the migrant labor market from 2002 to 2007. Our study is based on two comparable data sets: the 2002 wave of the China Household Income Project (CHIP) data, and the 2007 wave of the Rural-Urban Migration in China (RUMiC) data. Both data sets have a separated sample for migrants along with the standard urban sample and rural sample, which affords us a unique opportunity to systematically examine the change and evolution of the migrant labor market from 2002 to 2007. Our goal in this paper is to document fundamental facts and trends in the migrant labor market from 2002 to 2007, and to investigate the sources and causes of these facts and trends. Namely, we examine the rural-urban migration decision, the wage structure of migrants, urban labor market segmentation between migrants and urban natives, and the changes of these aspects from 2002 to 2007.

Our main findings are: First, during this 5-year period, there were dramatic changes in personal characteristics, working conditions, and migration behaviors of migrant workers. Recent migrants are younger, are more likely to be female, and have higher educational level. They are more likely to work in the manufacturing, wholesale and retail, restaurant, and hotel sectors. They also are likely to have more stable jobs and to hold longer-term labor contacts.

Second, rural people with prior migration experience have higher probability to migrate again, and the importance of prior migration experience increased from 2002 to 2007.

Third, the wages of both migrants and urban natives increased significantly from 2002 to 2007, but migrants have enjoyed faster wage growth. The average monthly wage increased about $61.4 \%$ and $60.5 \%$, and the hourly wage increased about $69.7 \%$ and $55.2 \%$, for migrants and urban natives, respectively. Our across-time decomposition analysis shows that the increase of wages from 2002 to 2007 among migrants and urban natives was mainly due to the price effect, i.e., the increase of coefficients of the characteristics.

Last, we also find evidence suggesting convergence of the urban labor markets for migrants and for urban natives during this 5-year period.

The remainder of the paper is structured as follows. In Section II, we describe our data sets in detail, and compare the profiles of the migrants in 2002 and in 2007. Section III analyzes the migration decision. In Section IV, we

\footnotetext{
${ }^{3}$ Migrants had been missing or underrepresented in most official statistics in China until the NBS conducted the $1 \%$ mini-census in 2005, which attempted to cover the migration population.
} 
investigate the wage structure of the migrants, compare their wage structure with its urban counterpart, and examine the wage change from 2002 to 2007. In Section V, we look into the labor market segmentation between migrants and urban natives, and document their convergence from 2002 to 2007. Section VI concludes the paper.

\section{Data, Descriptive Statistics, and Profile of Migrants}

\section{The CHIP and the RUMiC Data Sets}

The data sets used in this paper come from two different sources. The first one is the China Household Income Project (CHIP), which was carried out by the Institute of Economics at the Chinese Academy of Social Sciences with assistance from the NBS in China for the reference periods of 1988, 1995, and 2002. Besides the urban sample and rural sample, the 2002 wave of the CHIP also has a separated supplemental survey for rural-urban migrants in the cities. ${ }^{4}$

The second one is the Rural-Urban Migration in China (RUMiC) survey, which is conducted by an international team headed by researchers at Australian National University, with cooperation from Chinese scholars, and also with assistance from the NBS. The RUMiC survey is aimed to construct the first representative panel data sets on rural-urban migrants in China among its surveyed cities. Like the CHIP 2002 data, the RUMiC data also comprise three samples: rural, urban, and migrant. ${ }^{5}$ In this paper, we use the first wave (2007 wave) of the RUMiC data.

Both surveys record detailed information, such as income and expenditure, demographic characteristics, and work and employment information. We use the two data sources to construct a unique repeated cross-section data set to study the Chinese migrant labor market from 2002 to 2007.

\section{Comparability of the CHIP and the RUMiC Data Sets}

In this paper, we use all three samples from both sources. For the urban and rural samples, since both the CHIP and the RUMiC have carried out their urban and rural surveys with the help of the NBS, and drawn their observations from the NBS sampling frame, comparability is less a problem than it might have been.

However, it is important to note that the sampling frames for migrant samples are different in these two surveys. In the CHIP 2002, sampling is based on the residence of migrants. Migrants living in a dormitory or a workplace (such as a construction site) are not included in the sample. In the RUMiC 2007,

\footnotetext{
${ }^{4}$ For the details about the CHIP data and the supplementary survey, see Li et al. (2008).

${ }^{5}$ For the details about the RUMiC data, see Kong (2010).
} 
sampling is based on workplaces, and it covers migrants living in a dormitory or workplace. In order to make these two migrant data sets comparable, we exclude those migrants living in a dormitory or workplace. The remaining migrants, who have fixed residences, represent the better-off part of the migrant population, so we have to stipulate that our analysis is based on a more prosperous than average migrant population, and our results should be interpreted accordingly. ${ }^{6}$

\section{Selection of the Samples}

For the urban and migrant samples, we limit our observations to persons residing in the same city in both 2002 and 2007. There are seven cities presented in both waves; they are Wuxi, Hefei, Zhengzhou, Wuhan, Guangzhou, Chongqing, and Chengdu. We further restrict our data to people with ages from 16 to 60 for men and from 16 to 55 for women, since according to Chinese regulations, the retirement age for males is 60, and for females is 55. For the wage structure analysis, we only keep the employed individuals with a positive wage. $^{7}$

We follow a similar procedure to deal with the rural samples. First, we restrict our observations to the provinces presented in both 2002 and 2007. Nine provinces are covered in our final rural data; they are Hebei, Jiangsu, Zhejiang, Anhui, Henan, Hubei, Guangdong, Chongqing, and Sichuan. To make the rural, urban, and migrant samples comparable, we also impose the same age restrictions on the rural sample, even though a lot of rural people still work beyond age 60 in China.

\section{Descriptive Statistics and the Profile of Migrants}

\section{A. Comparison of Urban Natives and Migrants}

Appendix Table 1 presents summary statistics on household and individual characteristics, work-related variables, etc., for both migrants and urban natives.

On the individual level, the distribution of genders is very similar for urban natives and migrants; both have fewer females. The migrants are younger than their native counterparts. From 2002 to 2007, both migrants and urban natives decreased in average age. The average age was 34.6 in 2002 and 32.1 in 2007 for migrants, and 40.7 in 2002 and 38.8 in 2007 for urban natives.

From this table, we can also see that migrants are more likely to be married and to belong to a minority. ${ }^{8}$ The percentages of married and of

\footnotetext{
${ }^{6}$ The migrants who live in a dormitory or workplace are younger, are less likely to be married, earn less, and are less likely to be self-employed. Detailed descriptive statistics are available upon request.

${ }^{7}$ We tabulate the unemployment rate of migrants, but the number is quite small and shows almost no change during the period, so we only analyzed the working sample.

${ }^{8}$ The higher marriage rate in the migrant sample reflects the fact that we only include the migrants with fixed residence in our analysis.
} 
minority status for urban natives remained very stable from 2002 to 2007. However, these percentages have decreased for migrants during this period.

As to education, it is no surprise that migrants have less schooling than urban natives do, and the educational level for both natives and migrants has increased significantly from 2002 to 2007, especially for the migrants. The table also presents self-reported health status. Most migrants think their health is good, and their share of good health is much higher than that of the urban natives in 2002, but the time trends are different for these two groups. While the share of good health among migrants became smaller from 2002 to 2007, it increased for urban natives.

The table also summarizes information on work-related variables, such as the types of labor contract, industries, ownership, and location. There are five types of labor contract that the workers hold. Generally, the share of migrants who have a permanent or long-term labor contract is very low. By contrast, the share of self-employed is much higher among migrants. There are also large differences in industries of employment and in ownership status between migrants and urban natives. ${ }^{9}$

From the table, it is obvious that the wages of migrants are significantly lower than the wages of urban natives in both years. However, there is significant wage increase for both groups during this 5-year period. The monthly wages of migrants and urban natives have increased from 873.8 to 1410.5 Chinese yuan (increased by $61.4 \%$ ) and from 1172.8 to 1883.0 Chinese yuan (increased by $60.5 \%)$, respectively; the hourly wages of these two groups have increased from 3.2 to 5.5 yuan (increased by $69.7 \%$ ) and from 6.8 to 10.5 yuan (increased by $55.2 \%)$.

\section{B. Migrants vs. Nonmigrants, Based on the Rural Sample}

Since the migrant sample only contains migrants by definition, we also utilize the rural sample to compare the migrants and nonmigrants in the rural population.

Appendix Table 2 gives summary statistics of the rural samples in 2002 and 2007. We further divide the samples into migrant and nonmigrant groups. Generally, people in the migrant group are likely to be male, younger, and unmarried. From 2002 to 2007, there are some changes in both groups. As to gender composition, the share of males dropped from $66.7 \%$ to $63.2 \%$ in the migrant group, while it increased from $49.4 \%$ to $52.3 \%$ in the nonmigrant group. The two groups also show different patterns in age variation. From 2002 to 2007, migrants became younger: their average age decreased from 30.2 to 28.6 , while that of nonmigrants increased from 37.4 to 40.5.

More importantly, there is a significant difference in prior migration

\footnotetext{
${ }^{9}$ We will come back to these points in detail in the next section.
} 
experience between these two groups. In the migrant group, the share having prior migration experience was about $38.9 \%$ in 2002 , but was only $11.2 \%$ in the nonmigrant group in the same year. By 2007, the share had increased greatly, to $97 \%$, in migrant group. In the nonmigrant group, however, it had only increased to $19.5 \%$.

\section{Profiles of Migrants in 2002 and 2007, Based on Migrant Samples}

The profiles of migrants in 2002 and 2007 exhibit some differences. We highlight the key changes in age, educational attainment, employment industries, and types of labor contract.

Figure 1 shows the age structure and its change from 2002 to 2007 by male and female and by migrants and urban natives. In general, migrants are younger than urban natives. The remarkable fact is that the shares of migrants with ages 16-20 and 21-25 have increased a lot, especially for women. However, these shares for their urban counterparts have only increased a little. This is consistent with the fact that the migrant workers are getting younger.

$<$ Figure 1 Here $>$

The educational level for both migrants and urban natives has improved. However, for the migrants, the improvement comes from the fact that more people finished high school; for the urban natives, more of them received a college education. See Figure 2.

$<$ Figure 2 Here $>$

Figure 3 shows the distribution of migrants and urban natives among industries. A majority of migrants work in the service sector, such as wholesale, retail, restaurants, and hotels. A large portion of migrants also work in the manufacturing sector. Urban natives are more evenly distributed among industries, though manufacturing is the largest one, and its share is about 20\%-30\%. From 2002 to 2007, the employment distributions of migrants and urban natives follow different trends. The share of employment in the manufacturing sector increased significantly for migrants; however, for urban natives it dropped by $10 \%$. In the service sector, the opposite change happened, i.e., we see a decreased share of migrants employed in the service sector, but an increased share of urban natives.

$<$ Figure 3 Here $>$

For the types of labor contract, the most dramatic change is that the percentage of migrants who hold long-term contracts increased drastically, from $5 \%$ to $26 \%$; see Figure 4 . For the urban natives, the shares of different types of labor contract are more evenly distributed. From 2002 to 2007, most of the change happened in the group holding long-term contracts; the share of this group increased from $27 \%$ to almost $40 \%$. 
$<$ Figure 4 Here $>$

Figure 5 and Figure 6 are about the migration duration and job mobility of migrants. The migration duration decreased from 2002 to 2007; meanwhile, the migrants showed a decrease in job mobility, i.e., their jobs were more stable in 2007, which is consistent with the increase of long-term labor contracts among migrants.

$<$ Figure 5 and Figure 6 Here $>$

\section{Migration Decision}

\section{Migration Decisions in 2002 and 2007}

There are many changes in the profile of migrants from 2002 to 2007 . To examine these changes during the 5-year period, it is useful to explore the migration decisions among the rural households during this period. In this analysis, we utilize the rural household samples in 2002 and 2007; these samples allow us to identify the migrants and nonmigrants. ${ }^{10}$

We use a logit model to study the effect of personal, household, and village characteristics on the migration decisions in 2002 and 2007. Appendix Table 3 presents the results for all individuals, for men, and for women. This table also presents marginal effects of explanatory variables on the probability of migration. ${ }^{11}$

As can be seen from this table, there are several important factors that affect the migration decisions of rural population. At the personal level, the most important one is prior migration experience, and it shows a huge positive effect on migration decisions. Specifically, for those with prior migration experience, the migration probabilities were $23.5 \%$ and $46.1 \%$ greater than for those with no such experience in 2002 and 2007, respectively. Gender and age are also important. A male had higher probability to migrate than a female did - by $9.5 \%$ in 2002 , but only by $1.9 \%$ in 2007 . After controlling for age squared, age had a positive effect on migration decisions, but the effect went down from 2002 to 2007 . Marriage reduced the probability of migration by $11.9 \%$ in 2002 and by $3.7 \%$ in 2007 . The coefficients of educational level do not show the same patterns. In 2002, individuals with complete primary schooling or middle schooling were more likely to migrate than were people with less than complete primary schooling. But in 2007, the effects of education became insignificant.

As to the household characteristics, the number of preschool negatively

\footnotetext{
${ }^{10}$ We have to note that the migrants in rural samples might be different from those in the migrant samples; see Appendix Table 1 and Appendix Table 2. Part of the reasons are that the migrant samples only cover seven cities, and only include migrants with a fixed resident place.

11 The marginal effect for a continuous variable is evaluated at the sample mean, and that for a categorical variable is evaluated against the reference category.
} 
affected mother's migration decision, but not father's. The number of in-school children (age from 7 to 16) has a negative effect on migration decisions of both their mother and father, but the effect was diminished from 2002 to 2007, especially for the mother. The household size has a positive effect on migration probability, and this effect remained relatively stable during that 5-year period.

We now consider the village-level characteristics. Living in different geographic areas leads to different probabilities of migration with different time trends. Relative to living in a hilly area (reference group), living in a mountain area has a negative effect on migration in 2002 but a positive effect in 2007 . Living in a traditional revolutionary area or a minority village has a positive effect on migration, while living in a village in a suburb of a city has a negative effect. With regard to infrastructure, telephone access had a strong effect on migration in 2007; the distance to the city had a strong effect in 2002 , but by 2007 the effect had totally disappeared.

\section{Decomposition across Time}

To understand the change in migration decisions from 2002 to 2007 better, we use the decomposition method proposed by Yun (2004) to investigate the change over time. That method is an extension of classical Oaxaca-Blinder decomposition to nonlinear models, such as logit or probit models.

Based on Oaxaca (1973) and Blinder (1973), we can make the following decomposition:

$$
E\left[Y_{A}^{i}\right]-E\left[Y_{B}^{i}\right]=\left(E\left[X_{A}^{i}\right]-E\left[X_{B}^{i}\right]\right)^{\prime} \beta_{A}^{i}+E\left[X_{B}^{i}\right]^{\prime}\left(\beta_{A}^{i}-\beta_{B}^{i}\right)
$$

where $Y$ denotes the outcome, $X$ is a vector of variables determining the outcome, and $\beta$ can be seen as a vector of effects of these variables on the outcome. $A$ and $B$ denote any two groups between which there is a difference to be decomposed, such as black and white, or men and women. As indicated in the equation above, in the empirical implementation, the decomposition makes use of the sample mean of all characteristics and coefficients from the OLS for these characteristics. The first term on the right-hand side of this equation is the effect of differences in mean characteristics of the two groups for identical returns (coefficients): if the group $A$ had the endowment of the group $B$, what would the difference in outcome look like? This is usually termed the endowment effect. The second term is typically interpreted as the part of the gap of the outcome that is associated with differences in returns (coefficients) to the characteristics between the two groups, i.e., the coefficient effect, aka the price effect.

Following the spirits of Oaxaca-Blinder decomposition, Fairelie (1999 and 2005), Yun (2004), and Thomas and Mathias (2006) extend the decomposition to nonlinear models.

In this paper, we apply the decomposition framework in Yun (2004). His 
method not only allows calculating the endowment effect and the coefficient (price) effect, but also can isolate the endowment effect associated with an individual variable or a group of variables. His method is as follows:

$$
\overline{Y_{A}}-\overline{Y_{B}}=\sum_{i=1}^{K} W_{\Delta X}^{i}\left[\overline{F\left(X_{A} \beta_{A}\right)}-\overline{F\left(X_{B} \beta_{A}\right)}\right]+\sum_{i=1}^{K} W_{\Delta \beta}^{i}\left[\overline{F\left(X_{B} \beta_{A}\right)}-\overline{F\left(X_{B} \beta_{B}\right)}\right]
$$

where

$$
\begin{gathered}
W_{\Delta X}^{i}=\frac{\left(\bar{X}_{A}^{i}-\bar{X}_{B}^{i}\right) \beta_{A}^{i} f\left(\bar{X}_{A} \beta_{A}\right)}{\left(\bar{X}_{A}-\bar{X}_{B}\right) \beta_{A} f\left(\bar{X}_{A} \beta_{A}\right)}=\frac{\left(\bar{X}_{A}^{i}-\bar{X}_{B}^{i}\right) \beta_{A}^{i}}{\left(\bar{X}_{A}-\bar{X}_{B}\right) \beta_{A}} \\
W_{\Delta \beta}^{i}=\frac{\bar{X}_{B}^{i}\left(\beta_{A}^{i}-\beta_{B}^{i}\right) f\left(\bar{X}_{B} \beta_{B}\right)}{\bar{X}_{B}\left(\beta_{A}-\beta_{B}\right) f\left(\bar{X}_{B} \beta_{B}\right)}=\frac{\bar{X}_{B}^{i}\left(\beta_{A}^{i}-\beta_{B}^{i}\right)}{\bar{X}_{B}\left(\beta_{A}-\beta_{B}\right)}
\end{gathered}
$$

where the superscript $i=1, \cdots, K$ indicates the $i$ th group of variables, and where $W_{\Delta X}^{i}$ and $W_{\Delta \beta}^{i}$ are weights for the $x \mathrm{~s}$ in the ith group and their coefficients, with $\sum_{i=1}^{K} W_{\Delta X}^{i}=\sum_{i=1}^{K} W_{\Delta \beta}^{i}=1$

Table 1a reports the decomposition results. The first two rows report the share of migrants, and thus the propensity to migration, in 2002 and 2007. In 2002, the share of migrants is 0.207 , and this number increases to 0.252 in 2007 . If we investigate the migration propensity for males and females separately, we can see that males have a higher migration propensity in both years; however, the migration propensity of females increased faster during this period.

\section{$<$ Table 1a Here $>$}

We decompose the total change of the migration propensity into the price effect and the endowment effect. These two effects have different signs. The endowment effect, such as that of changes in human capital, household characteristics, and village characteristics, increases the probability of migration; the price effect, due to the changes of coefficients from 2002 to 2007, reduces the probability of migration.

To further understand the change in migration decisions, we isolate the contribution of every variable; see Tables $1 \mathrm{~b}$ for the endowment effect and $1 \mathrm{c}$ for the price effect. Migration experience, household size and age are the three most important factors. The endowment effects for both migration experience and age are positive, and the endowment effect for household size is negative; however, migration experience has a positive coefficient effect, and age has a negative one.

$<$ Table $1 \mathrm{~b}$ and Table 1c Here $>$ 


\section{Wage}

\section{Wage Structure and Inequality}

Table 2 describes the wages (both monthly and hourly) of migrants and urban natives in 2002 and 2007. The monthly wage of both urban natives and migrants increased sharply, by about $60.5 \%$ and $61.4 \%$ over this 5 -year period, respectively. It is clear that the migrants have enjoyed a faster growth of hourly than of monthly wage.

The table also shows what happened to wage inequality over the 5 -year period. We calculate different measures of inequality, such as the Gini coefficient, the Theil index, and Kuznets ratios (such as the wage ratio of the 90th to the 10th percentile). We find a very interesting phenomenon: the trends of inequality are strikingly different for migrants and urban natives. While earnings inequality among urban natives increased from 2002 to 2007, it decreased among migrants. ${ }^{12}$

\section{$<$ Table 2 Here $>$}

\section{Wage Equation}

To explain the increase of wages for urban native and migrant groups, we first estimate wage functions for the migrants and urban natives, including the usual explanatory variables, such as education, age, minority, marital status, health status, ownership of place of employment, industry of employment, type of labor contract, and province dummies in the wage equations. The dependent variable is the logarithm of the hourly wage.

Appendix Table 4 presents the OLS estimates of wage functions for both migrants and urban natives in 2002 and 2007 for the whole sample and for the male and female samples. It can be seen that there are important differences in the coefficients for the genders. For males, the coefficients for both urban natives and migrants are significant in 2002, but the coefficient becomes insignificant for urban natives in 2007, while it is still very significant for migrants in 2007, and even increases a little. This might mean that there is still gender discrimination in the migrant labor market.

The coefficients on educational level are one of our focuses. For both urban natives and migrants, the rates of return to education in both years are significant and positive; however the rate of return increased a little for migrants, and decreased by around $3 \%$ for urban natives, over the 5 years. ${ }^{13}$ Thus, human capital is getting more and more important for migrants, along with the marketization of the Chinese labor market. Combined with the previous

\footnotetext{
${ }^{12}$ In a separate project, we examine this phenomenon in detail.

13 The decrease of the rate of return to education among urban natives is an important phenomenon, and worth further investigation. We also run classical Mincerian wage equations, i.e. only include education, experience and experience squared (proxied by age and age squared) in the model, the fact that the rate of return to education decreased remains unchanged.
} 
migration decision analysis, this suggests that education is becoming more important in wage determination, but is becoming less important in migration decision.

\section{Decomposition of the Wage Equation from 2002 to 2007}

To understand the factors behind the wage increase, we use the Oaxaca-Blinder decomposition method to study the hourly-wage change over this 5-year period. Specifically, we apply the following decomposition equation:

$$
\begin{aligned}
& E\left[\ln Y_{2007}^{i}\right]-E\left[\ln Y_{2002}^{i}\right]=\left(E\left[X_{2007}^{i}\right]-E\left[X_{2002}^{i}\right]\right)^{\prime} \beta_{2007}^{i} \\
& +E\left[X_{2002}^{i}\right]^{\prime}\left(\beta_{2007}^{i}-\beta_{2002}^{i}\right)+\left(E\left[X_{2007}^{i}\right]-E\left[X_{2002}^{i}\right]\right)^{\prime}\left(\beta_{2007}^{i}-\beta_{2002}^{i}\right)
\end{aligned}
$$

where $Y$ denotes the hourly wage, $X$ is a vector of characteristics, and $\beta$ is a vector of returns to these characteristics; $i=1$ or 2 denotes migrants or urban natives, respectively.

Table 3 shows the decomposition results on the log of hourly wage. We find that the changes of endowments can only explain a small part of the wage increase (about $-5 \%$ for urban natives and $28 \%$ for migrants); most of the increase is due to changes of coefficients (91\% for urban natives and $100 \%$ for migrants). If we examine the decomposition results for men and women separately, the basic description remains unchanged.

$$
<\text { Table } 3 \text { Here }>
$$

To further explore the cause of the wage increase, we isolate the contributions of individual variables. As can be seen from Table 4, the endowment effects for both migrants and urban natives are positive, especially those from education. The change of the labor market segmentation favors the migrants, and the endowment effect for this change accounts for $29.1 \%$ of the migrants' wage increase. However, the urban natives do not benefit from the change of the labor market segmentation.

The coefficient effects from human capital are strikingly different for migrants and urban natives. The migrants benefit a lot from the increase of returns to age and education; however, the coefficient effects of both age and education are negative for urban natives. The former fact reflects that the return to seniority for Chinese urban natives has decreased significantly, which is consistent with the findings in Appleton, Song, and Xia (2005). The later is consistent with the observation that along with the expansion of higher education in China, the return to education, especially among the younger cohorts, shows a decreasing trend.

Though urban natives do not benefit from the change of the labor market segmentation itself, they do benefit from changes in coefficients associated with variables on the market segmentation, as do the migrants. That 
is consistent with the story that China is moving toward a functional labor market; see Dong and $\mathrm{Xu}$ (2009).

The last observation in our analysis is that the constant term is much more important for urban natives than for migrants. It hints that the wage of migrants is much less influenced by unobserved factors, such as nonmarket and labor market institutional factors. This also highlights the puzzling observation that the return to education among urban natives decreased over the period.

$<$ Table 4 Here $>$

\section{Labor Market Segmentation}

This section investigates the segmentation between urban natives and migrants in the labor market. We calculate the traditional index of dissimilarity proposed by Duncan and Duncan (1955). That Duncan index measures the evenness with which two groups, urban natives and migrants in our case, are distributed across the different industries. If the fractional distribution of migrants employed in all industries is the same as that of urban natives, the Duncan index gets score 0, which means that there is no segmentation at all in the labor market. On the contrary, if the distribution of migrants employed in all industrials is extremely different from that of urban natives, the Duncan index gets score 1, which means that the labor market is totally segmented. The formula for the Duncan index is

$$
D=\frac{1}{2} \sum_{j=1}^{J}\left|\left(\frac{U_{i}}{U}\right)-\left(\frac{M_{i}}{M}\right)\right|
$$

where $j=1,2, \ldots, J$ denotes the $t$ th industry, $U_{i}$ represents the number of urban natives employed in the $j$ th industry, $U$ represents the population of urban natives employed in all industries, and $M_{i}$ and $M$ have corresponding meanings for migrants.

The results are shown in Table 5. For the whole sample, the Duncan index decreased significantly, from 0.48 in 2002 to 0.38 in 2007. This suggests that the labor market is turning more competitive over time.

\section{$<$ Table 5 Here $>$}

We also calculated the Duncan index by gender, age, and educational level groups. In 2002, males had a higher degree of segmentation, and the Duncan index is 0.52 for males and 0.44 for females; but in 2007, the Duncan indices were similar for males and females, around 0.39 .

For age groups, in 2002 the index increased along with age. For example, the index for the group of ages 16-25 was only 0.37 , while the index for 45-60 was 0.57 . In 2007, however, the index had become much more even. The index 
for older groups had decreased more. For example, for the group of ages 16-25, the index remained unchanged while the indices for the other groups changed from 0.46 to $0.42,0.49$ to 0.41 , and 0.57 to 0.42 for $26-35,36-45$, and $45-60$, respectively.

The last part of the table gives the Duncan index by educational level group. There are some differences by educational level. In 2002, the group with the highest value of the index is the group with full primary education or less, and the value is 0.50 . But the group with the lowest value is not the group with college or graduate education; it is the group with high school education. In 2007, except for the group with college or graduate education, the indices for most groups had decreased. The group with middle school education had become the group with the lowest segmentation, and its index was 0.34 .

In a word, the analyses show that the labor market segmentation between migrants and urban natives in industry became weaker. There is a trend of convergence of labor markets for migrants and urban natives. The convergent rates are faster for males, older people, and people with middle school education

\section{Conclusions}

Based on a newly acquired unique data set (RUMiC), along with the CHIP data, this paper studies the dynamics of the migrant labor market in the beginning of the 21st century.

We find that during the 5-year period, there were many changes in the profile of migrants. The new migrants are younger, are more likely to be female, and have higher education level than the old cohort. The new migrants are more likely to work in the manufacturing, wholesale and retail, restaurant, and hotel sectors. They also are more likely to hold more stable jobs and have longer labor contracts.

Our decomposition exercise shows that the increase of the probability of migration in driven by the endowment effect. Indeed, the coefficient effect is negative. Prior migration experience was a key factor for migration decisions in 2002 and 2007, and its importance is increasing over time.

From 2002 to 2007, the wages of both migrants and urban natives increased significantly. Our across-time decomposition analysis shows that the increase mainly results from the coefficient effect for both groups.

We further look into different categories of explanatory variables. The endowment effects of human capital are positive for both migrants and urban natives. However, the coefficient effects from human capital are quite different for migrants and urban natives. The migrants benefit a lot from the increase of returns to age and education; meanwhile, the coefficients effects of age and education are negative for urban natives. 
The change of the labor market segmentation favors the migrants; the urban natives do not benefit from this change. Though urban natives do not benefit from the change of the labor market segmentation itself, they do benefit from changes in coefficients associated with variables connected with market segmentation, as do the migrants.

We also find evidence suggesting that the segmentation between migrants and urban natives in the labor market is becoming weaker. There is a convergence of urban labor markets for the migrants as well as for the urban natives during this 5 -year period. 


\section{References}

Appleton, Simon, Lina Song, and Qingjie Xie, 2005. Has China Crossed the River? The Evolution of Wage Structure in Urban China during Reform and Retrenchment. Journal of Comparative Economics, 33: 688-709

Blinder, Alan, 1973. Wage Discrimination: Reduced Form and Structural Estimates. Journal of Human Resources, 8: 436-455.

Cai, Fang, 2008. Approaching a Triumphal Span: How Far is China towards Its Lewisian Turning Point? WIDER Research Paper, rp2008-09.

Demurger, Sylvie, Martin Gurgand, Shi Li, and Ximing Yue, 2009. Migrants as Second-class Workers in Urban China? A Decomposition Analysis. Journal of Comparative Economics, 37: 610-628.

Deng, Quheng and Shi Li, 2010. Wage Structures and Inequality among Local and Migrant and Urban Workers. In The Great Migration: Rural-Urban Migration in China and Indonesia, eds. Meng, Xin, Chris Manning, Shi Li, and Tadjuddin Noer Effendi, Edward Elgar Publishing Ltd, 2010.

Dong, Xiao-yuan and Lixin Xu, 2009. Labor Restructuring in China: Toward a Functional Labor Market. Journal of Comparative Economics, 37: $287-305$.

Duncan, Otis Dudley and Beverly Duncan, 1955. A Methodological Analysis of Segregation Indexes. American Sociological Review, 20(2): 210-217.

Fairlie, Robert W., 1999. The Absence of the African-American Owned Business: An Analysis of the Dynamics of Self-Employment. Journal of Labor Economics, 17(1): 80-108.

Fairlie, Robert W., 2005. An Extension of the Blinder-Oaxaca Decomposition Technique to Logit and Probit Models. Journal of Economic and Social Measurement, 30: 305-316.

Knight, John and Lina Song, 2003. Increasing Urban Wage Inequality in China, The Economics of Transition, 11(4): 597-619.

Knight, John and Linda Yueh, 2009. Segmentation or Competition in China's 
Urban Labour Market, Cambridge Journal of Economics, 33(1): 79-94.

Kong, T. Sherry, 2010. Rural-Urban Migration in China: Survey Design and Implementation. In The Great Migration: Rural-Urban Migration in China and Indonesia, eds. Meng, Xin, Chris Manning, Shi Li, and Tadjuddin Noer Effendi, Edward Elgar Publishing Ltd, 2010.

Li, Shi, Chuliang Luo, Zhong Wei and Ximing Yue, 2008. Appendix: The 1995 and 2002 Household Surveys: Sampling Methods and Data Description. In Inequality and Public Policy in China, eds. B. Gustafsson, S. Li, and T. Sicular, Cambridge University Press, 2008.

Meng, Xin, and Junsen Zhang, 2001. The Two-Tier Labor Market in Urban China, Journal of Comparative Economics, 29, 485-504.

National Bureau of Statistics, 2009. The Total Number of Off-Farm Rural Laborers Reached 225.42 Millions at the End of 2008. (Source: the NBS webpage: http://www.stats.gov.cn/tjfx/fxbg/t20090325_402547406.htm, last accessed: December 10, 2010)

Oaxaca, Ronald, 1973. Male-Female Wage Differentials in Urban Labor Markets, International Economic Review, 14, 693-709.

Thomas, B. and S. Mathias. 2006. An Extension of the Blinder-Oaxaca Decomposition to Non-Linear Models. RWI Discussing Paper: No. 49.

Yun, M. 2004. Decomposing differences in the first moment. Economics Letters, $82(2): 275-280$.

Zhao, Yaohui, 2001. Leaving the Countryside: Rural-to-Urban Migration Decisions in China, American Economic Review, 89(2): 281-86.

Zhao, Yaohui, 2003. The Role of Migrant Networks in Labor Migration: The Case of China. Contemporary Economic Policy, 21(4): 500-511.

Zhao, Zhong, 2005. Migration, Labor Market Flexibility, and Wage Determination in China: A Review, Developing Economies, 43: 285-312.

Zhu, Nong, 2002. The Impacts of Income Gaps on Migration Decisions in China, China Economic Review, 13, 213-30. 
Figure 1. Age: Migrants vs. Urban Natives: 2002-2007

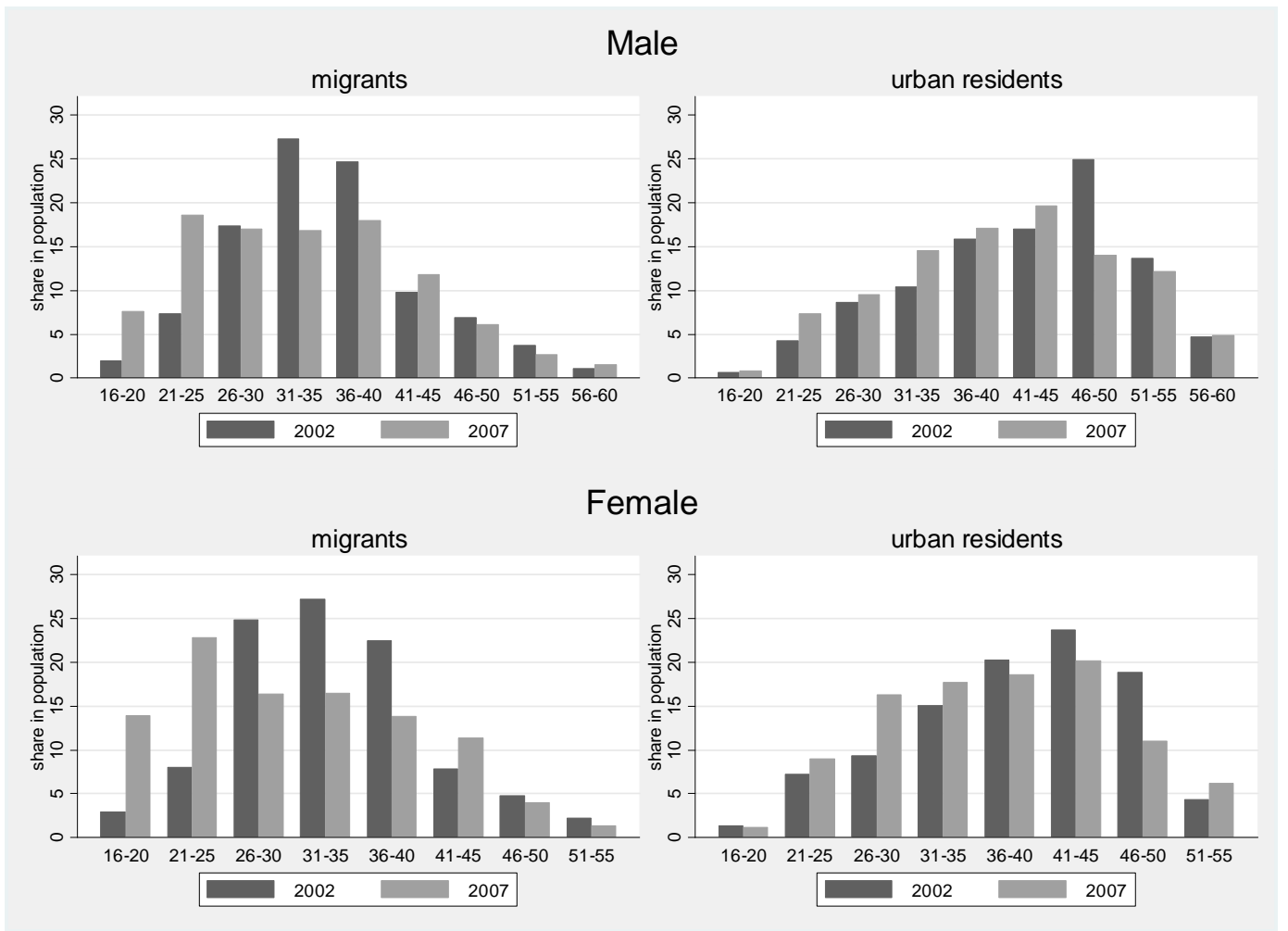

Figure 2. Education: Migrants vs. Urban Natives: 2002-2007

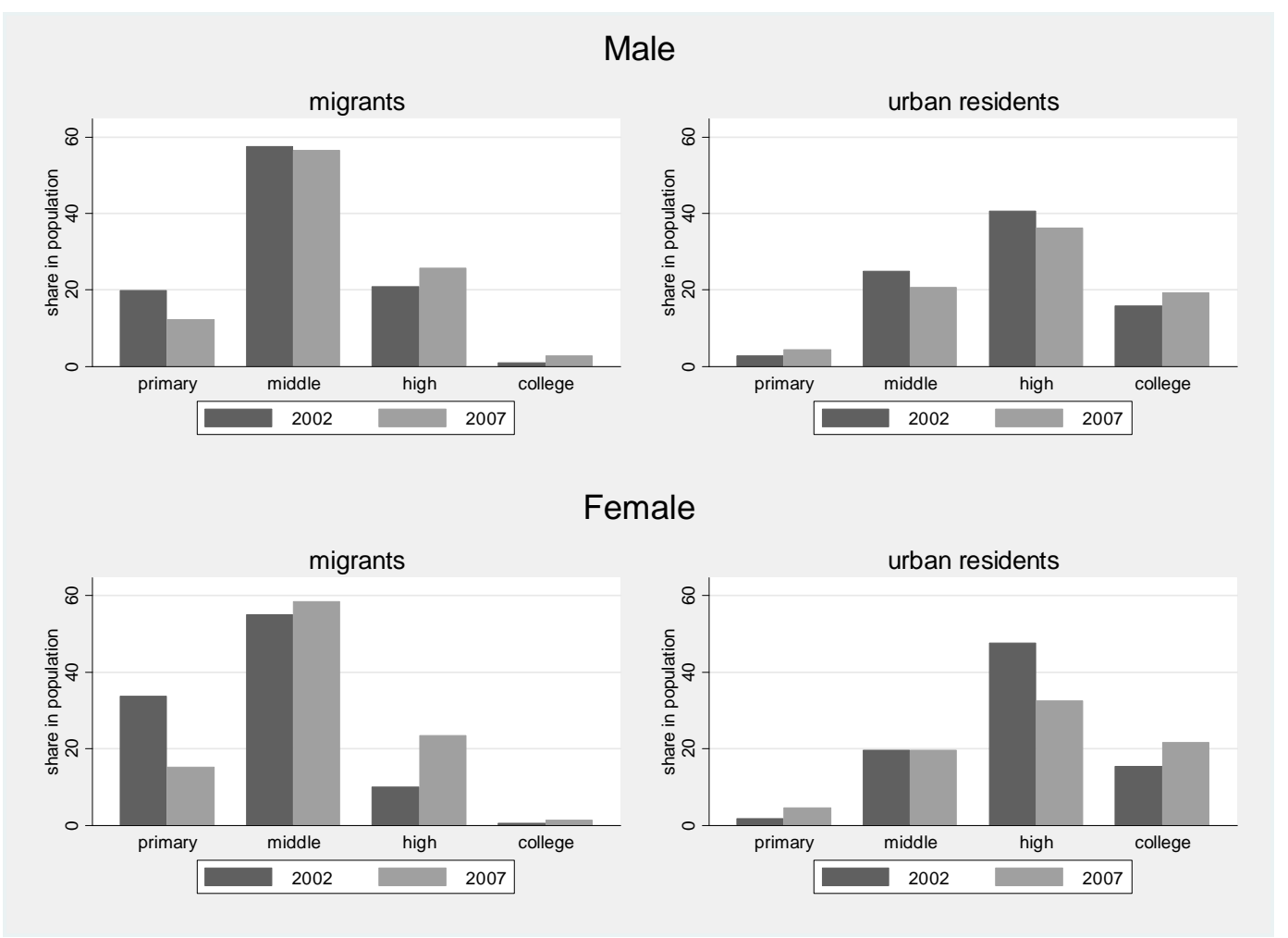


Figure 3. Industry: Migrants vs. Urban Natives: 2002-2007

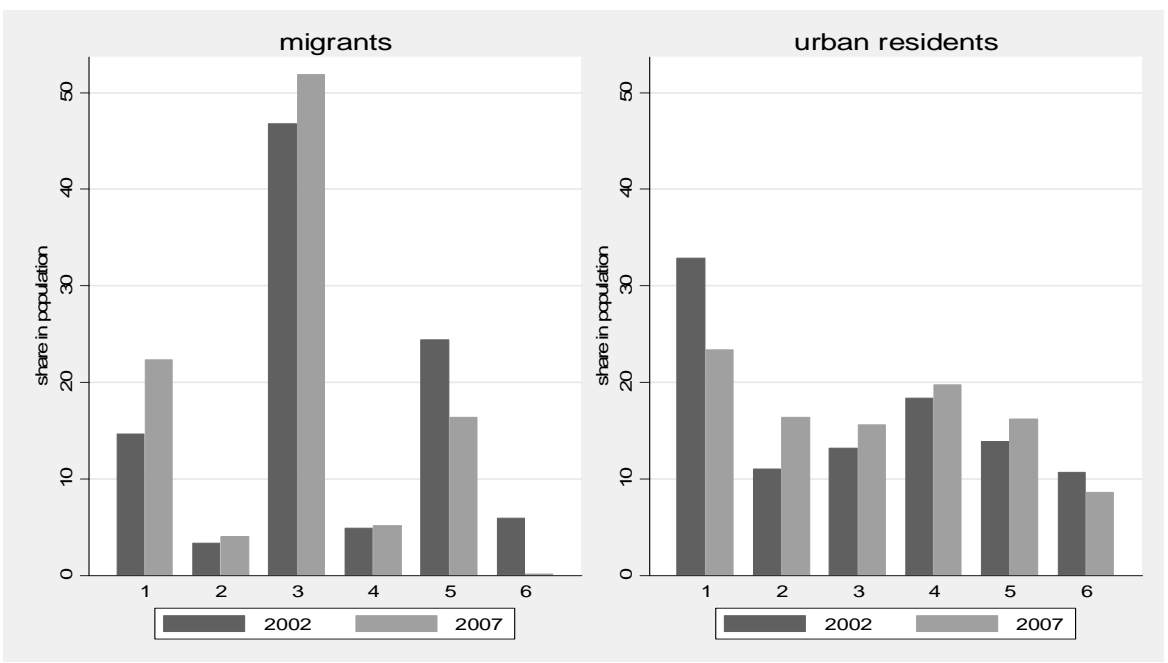

Note: 1 , agriculture + mineral + manufacturing + construction; 2 , electricity, gas, and water and transportation and IT; 3, wholesale and retail, restaurant, and hotel; 4, finance + real estate, health and social security + education, arts and media + science and technical services; 5 , services; 6 , goverment and public administration and others.

Figure 4. Type of Labor Contract: Migrants vs. Urban Natives: 2002-2007

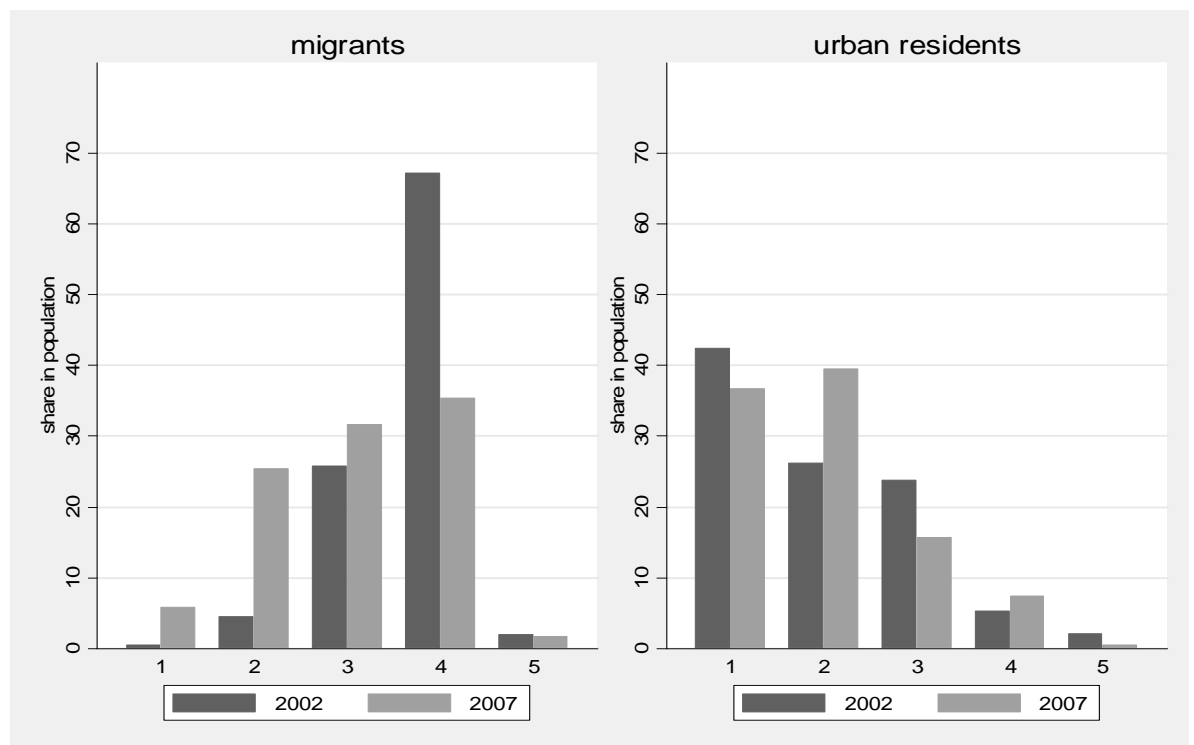

Note: 1, permanent; 2, long-term temporary; 3, short-run temporary or no contract; 4, self-employed; 5 , others 
Figure 5. Migration Duration: 2002-2007

(Year)

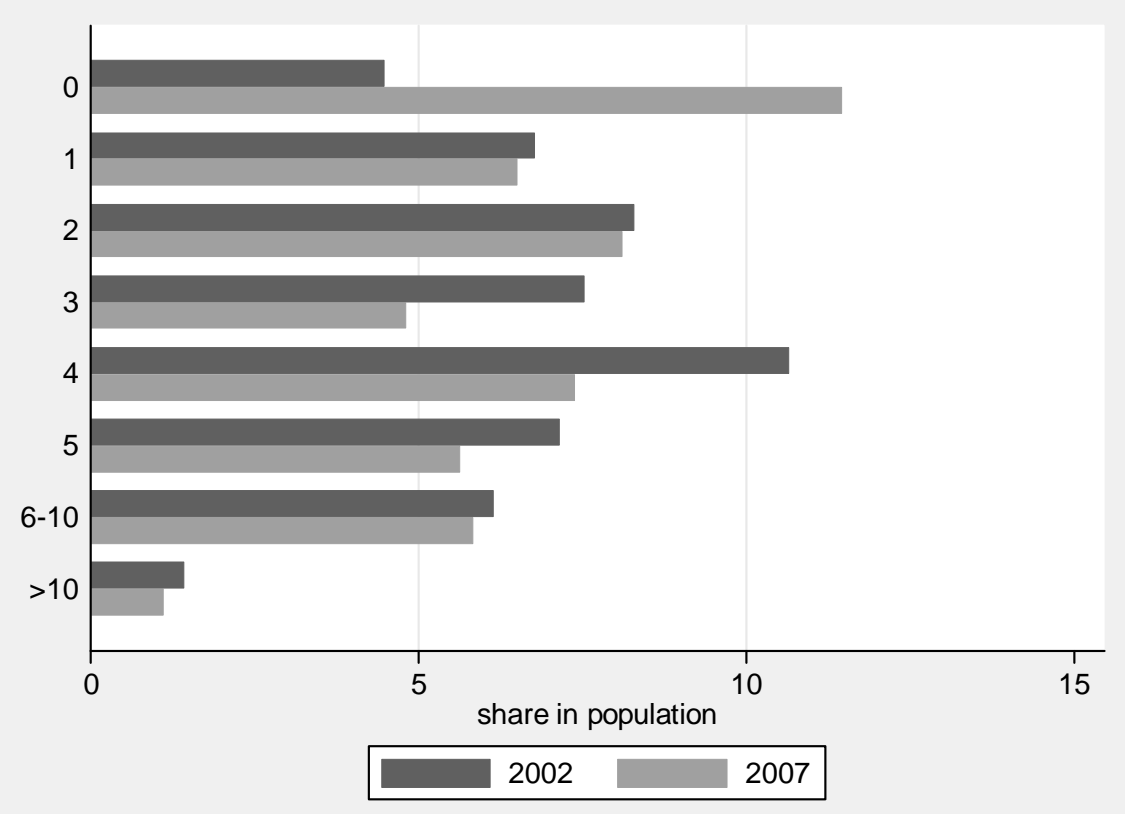

Figure 6. Mobility of Migrants: 2002-2007

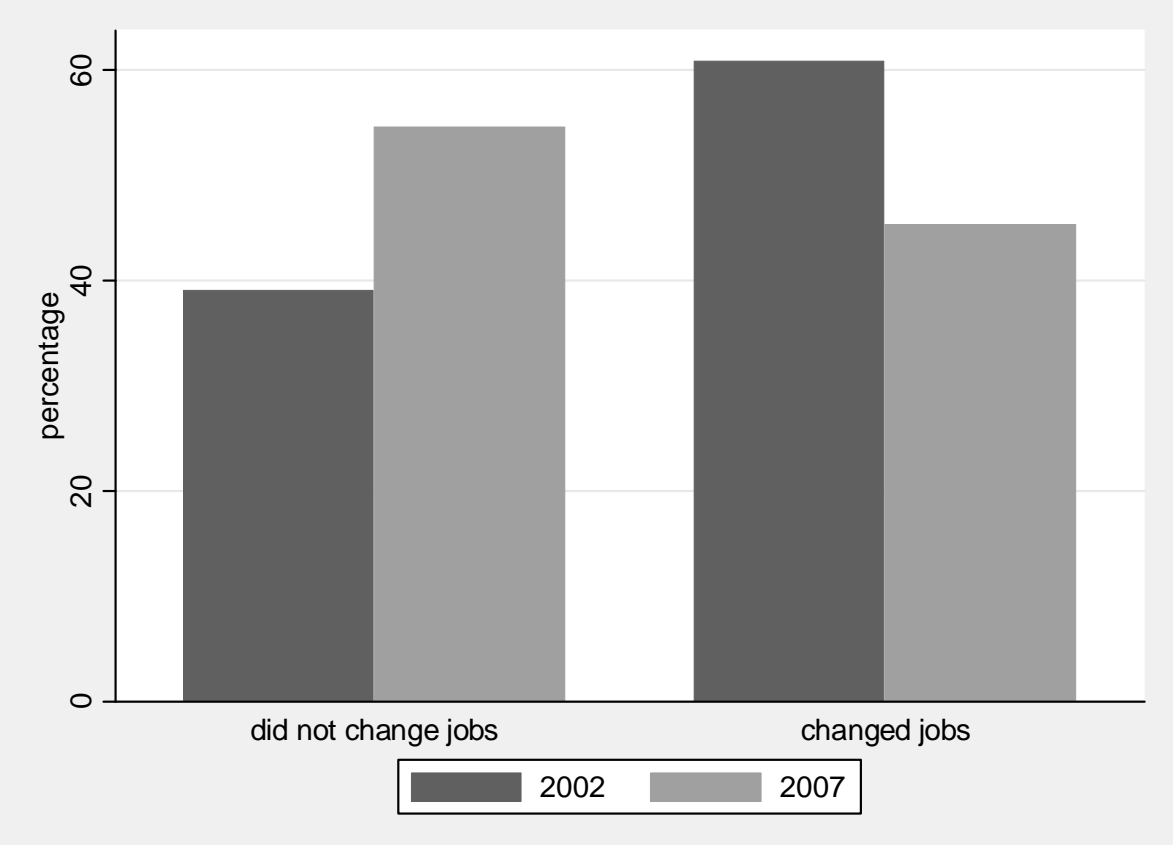


Table 1a. Decomposition for Migration Decision: 2002-2007

\begin{tabular}{|c|c|c|c|c|c|c|}
\hline \multirow{2}{*}{ Share of Migrants } & \multicolumn{2}{|c|}{ All } & \multicolumn{2}{|c|}{ Male } & \multicolumn{2}{|c|}{$\overline{\text { Female }}$} \\
\hline & & & & & & \\
\hline 2002 & 0.207 & & 0.261 & & 0.146 & \\
\hline 2007 & 0.252 & & 0.289 & & 0.206 & \\
\hline Difference btween 2002 and 2007 & 0.045 & & 0.028 & & 0.06 & \\
\hline & Coef. & Share & Coef. & Share & Coef. & Share \\
\hline Endowment Effect & $\begin{array}{l}0.134 \\
{[0.003]}\end{array}$ & $299.70 \%$ & $\begin{array}{l}0.14778 \\
{[0.004]}\end{array}$ & $519.99 \%$ & $\begin{array}{l}0.11456 \\
{[0.004]}\end{array}$ & $192.20 \%$ \\
\hline Coefficient Effect & $\begin{array}{l}-0.089 \\
{[0.004]}\end{array}$ & $-199.70 \%$ & $\begin{array}{l}-0.11936 \\
{[0.007]}\end{array}$ & $-419.99 \%$ & $\begin{array}{l}-0.054958 \\
{[0.006]}\end{array}$ & $-92.20 \%$ \\
\hline Number of Observations & & 748 & & 702 & & 046 \\
\hline
\end{tabular}

Note: Numbers inside square brackets are standard errors; 
Table 1b. Endowment Effect for Migration Decision: 2002-2007

\begin{tabular}{lrrrrrrr}
\hline \hline & \multicolumn{2}{c}{ All } & \multicolumn{2}{c}{ Male } & \multicolumn{2}{c}{ Female } \\
\cline { 2 - 7 } & \multicolumn{1}{c}{ Coef. } & Std. Error & Coef. & Std. Error & Coef. & Std. Error \\
\hline Male & 0.001 & 0 & & & & \\
Migration experience & 0.142 & 0.006 & 0.162 & 0.007 & 0.116 & 0.01 \\
& & & & & & & \\
Human Capital & & & & & & \\
Age & 0.024 & 0.005 & 0.033 & 0.007 & 0.017 & 0.007 \\
Age squared & -0.035 & 0.005 & -0.049 & 0.007 & -0.022 & 0.006 \\
Primary school & 0.001 & 0.001 & -0.001 & 0.001 & 0.002 & 0.001 \\
Middle school & 0 & 0 & 0 & 0 & 0.003 & 0.001 \\
High school & 0 & 0 & 0 & 0 & 0 & 0
\end{tabular}

Household Characteristics

$\begin{array}{lrrrrrr}\text { Married } & -0.005 & 0.001 & -0.003 & 0.001 & -0.007 & 0.001 \\ \text { Child between 0-6 } & 0.004 & 0.004 & 0 & 0.005 & 0.009 & 0.006 \\ \text { Child between 7-16 } & 0.019 & 0.006 & 0.023 & 0.007 & 0.015 & 0.009 \\ \text { Household size } & -0.036 & 0.004 & -0.035 & 0.005 & -0.04 & 0.007\end{array}$

Village Characteristics

$\begin{array}{lrrrrrr}\text { Plain area } & 0.001 & 0.001 & 0 & 0.001 & 0.003 & 0.002 \\ \text { Mountain area } & 0.001 & 0 & 0.001 & 0 & 0.001 & 0 \\ \text { Revolution area } & 0.002 & 0 & 0.002 & 0.001 & 0.002 & 0.001 \\ \text { Minority village } & 0.001 & 0 & 0.001 & 0 & 0.001 & 0 \\ \text { Suburb village } & 0 & 0 & 0 & 0 & 0 & 0 \\ \text { Road access } & -0.001 & 0.001 & -0.002 & 0.001 & 0 & 0.001 \\ \text { Telephone access } & 0.001 & 0.001 & 0.002 & 0.001 & 0.001 & 0.001 \\ \text { Distance to the city: } & & & & & & \\ 2-5 \mathrm{~km} & 0.001 & 0.001 & 0.002 & 0.001 & 0 & 0.001 \\ 5-10 \mathrm{~km} & 0.001 & 0.001 & 0.002 & 0.001 & -0.001 & 0.001 \\ \text { 10-20 km } & 0 & 0 & 0 & 0 & 0 & 0 \\ \text { Over 20 km } & 0.001 & 0.001 & 0 & 0.002 & 0.004 & 0.002 \\ & & & & & & \\ \text { Jiangsu } & & & & & & 0.001 \\ \text { Zhejiang } & 0.004 & 0 & 0.004 & 0 & 0.004 & 0.001 \\ \text { Anhui } & -0.001 & 0 & -0.001 & 0 & -0.002 & 0.001 \\ \text { Henan } & -0.002 & 0 & -0.001 & 0 & -0.003 & 0 \\ \text { Hubei } & -0.002 & 0 & -0.002 & 0 & -0.003 & 0.001 \\ \text { Guangdong } & 0.005 & 0 & 0.004 & 0.001 & 0.006 & 0.001 \\ \text { Chongqing } & 0 & 0 & 0 & 0 & 0 & 0 \\ \text { Sichuan } & 0.004 & 0 & 0.003 & 0 & 0.005 & 0.001 \\ & 0.004 & 0 & 0.004 & 0 & 0.005 & 0.001 \\ & & & & & & \end{array}$

\begin{tabular}{lccc}
\hline Number of Observations & 30748 & 16702 & 14046 \\
\hline \hline
\end{tabular}


Table 1c. Coefficient Effect for Migration Decision: 2002-2007

\begin{tabular}{lrrrrrrr}
\hline \hline & \multicolumn{3}{c}{ All } & \multicolumn{3}{c}{ Male } & \multicolumn{2}{c}{ Female } \\
\cline { 2 - 7 } & Coef. & Std. Error & Coef. & Std. Error & Coef. & Std. Error \\
\hline Male & -0.009 & 0.002 & & & & \\
Migration experience & 0.023 & 0.001 & 0.04 & 0.002 & 0.011 & 0.001 \\
& & & & & & & \\
Human Capital & & & & & & & \\
Age & -0.26 & 0.049 & -0.391 & 0.081 & & -0.272 & 0.075 \\
Age squared & 0.127 & 0.027 & 0.191 & 0.044 & 0.154 & 0.043 \\
Primary school & -0.002 & 0.002 & -0.002 & 0.003 & 0.001 & 0.003 \\
Middle school & -0.007 & 0.004 & -0.01 & 0.007 & 0.001 & 0.004 \\
High school & 0 & 0.001 & 0.001 & 0.002 & 0.001 & 0.001
\end{tabular}

Household Characteristics

$\begin{array}{lrrrrrr}\text { Married } & 0.007 & 0.004 & -0.001 & 0.007 & 0.017 & 0.006 \\ \text { Child between 0-6 } & -0.001 & 0.002 & -0.001 & 0.002 & 0 & 0.002 \\ \text { Child between 7-16 } & 0 & 0.003 & -0.003 & 0.004 & 0.005 & 0.003 \\ \text { Household size } & 0.031 & 0.007 & 0.058 & 0.011 & 0.014 & 0.009\end{array}$

Village Characteristics

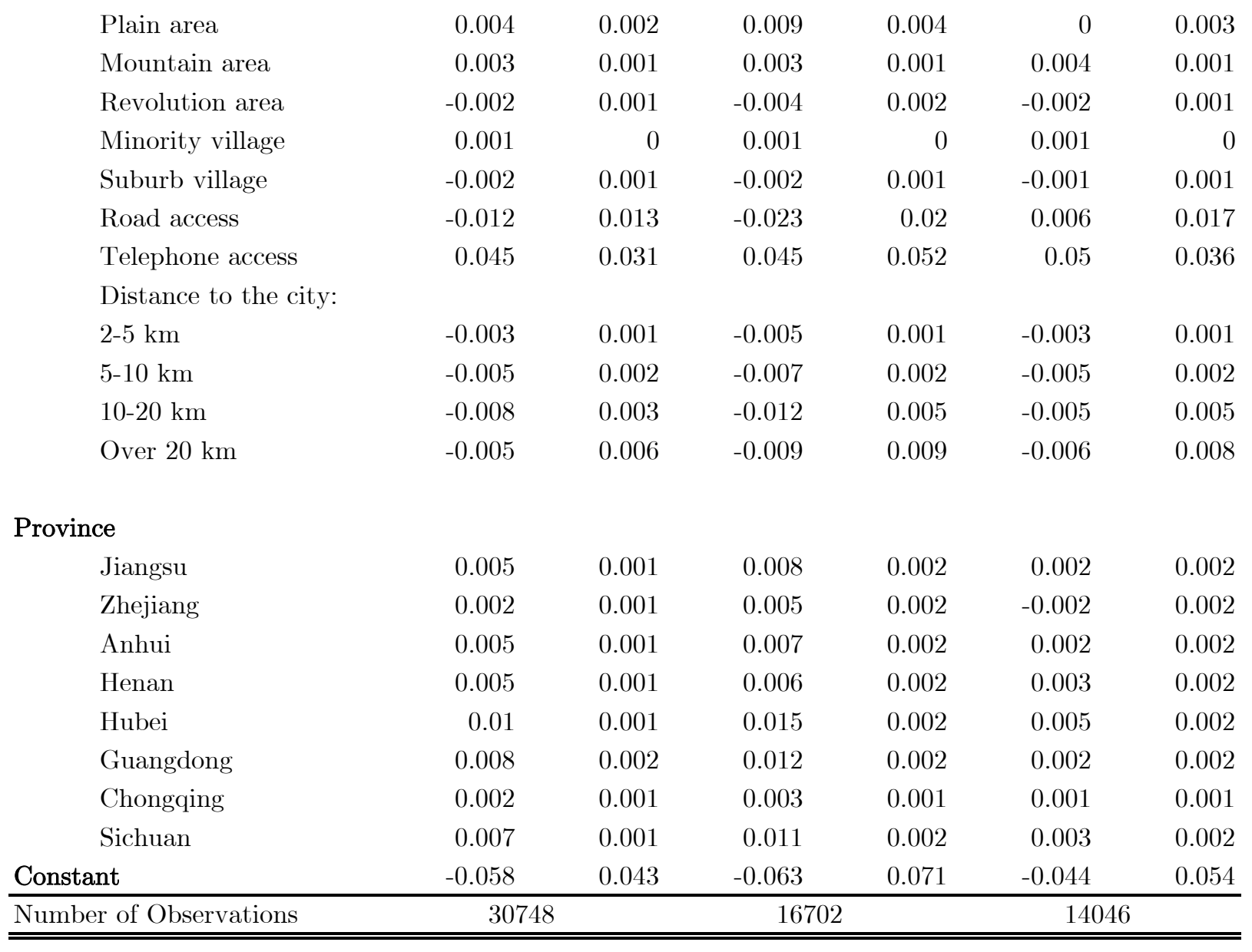

Province 
Table 2. The Structure of Wage of Urban Residents and Migrants in 2002 and 2007

\begin{tabular}{|c|c|c|c|c|c|c|c|c|c|c|c|c|}
\hline & \multicolumn{6}{|c|}{ Monthly Wage } & \multicolumn{6}{|c|}{ Hourly Wage } \\
\hline & \multicolumn{3}{|c|}{ Urban Native } & \multicolumn{3}{|c|}{ Migrant } & \multicolumn{3}{|c|}{ Urban Native } & \multicolumn{3}{|c|}{ Migrant } \\
\hline & \multirow{2}{*}{\multicolumn{2}{|c|}{ Wage }} & \multirow{2}{*}{$\begin{array}{c}\text { Wage } \\
\text { Growth } \\
(\%)\end{array}$} & \multirow{2}{*}{\multicolumn{2}{|c|}{ Wage }} & \multirow{2}{*}{$\begin{array}{c}\text { Wage } \\
\text { Growth } \\
(\%)\end{array}$} & \multirow{2}{*}{\multicolumn{2}{|c|}{ Wage }} & \multirow{2}{*}{$\begin{array}{c}\text { Wage } \\
\text { Growth } \\
(\%)\end{array}$} & \multirow{2}{*}{\multicolumn{2}{|c|}{ Wage }} & \multirow{2}{*}{$\begin{array}{c}\text { Wage } \\
\text { Growth } \\
(\%)\end{array}$} \\
\hline & & & & & & & & & & & & \\
\hline & 2002 & 2007 & $2002-07$ & 2002 & 2007 & $2002-07$ & 2002 & 2007 & $2002-07$ & 2002 & 2007 & $2002-07$ \\
\hline Mean & 1172.8 & 1882.64 & 60.53 & 873.8 & 1410.39 & 61.41 & 6.76 & 10.5 & 55.19 & 3.23 & 5.49 & 69.72 \\
\hline 10th percentile & 400 & 654.6 & 63.65 & 400 & 684.6 & 71.15 & 2.07 & 3.25 & 57.18 & 1.11 & 2.19 & 97.48 \\
\hline Median & 973.63 & 1456.99 & 49.65 & 650 & 1166.53 & 79.47 & 5.47 & 7.84 & 43.42 & 2.22 & 4.36 & 96.38 \\
\hline 90th percentile & 2166.67 & 3548.32 & 63.77 & 1500 & 2243.32 & 49.55 & 12.72 & 20.39 & 60.3 & 5.34 & 9.54 & 78.53 \\
\hline Ratio of 90 th to 10 th percentile & 5.42 & 5.42 & 0 & 3.75 & 3.28 & -12.53 & 6.16 & 6.28 & 1.99 & 4.81 & 4.35 & -9.6 \\
\hline Ratio of 90 th to median & 2.23 & 2.44 & 9.42 & 2.31 & 1.92 & -16.88 & 2.33 & 2.6 & 11.77 & 2.41 & 2.19 & -9.09 \\
\hline \multirow[t]{2}{*}{ Ratio of median to 10 th percentile } & 2.43 & 2.23 & -8.23 & 1.63 & 1.7 & 4.29 & 2.65 & 2.42 & -8.75 & 2 & 1.99 & -0.56 \\
\hline & 2002 & 2007 & Change & 2002 & 2007 & Change & 2002 & 2007 & Change & 2002 & 2007 & Change \\
\hline Gini coefficient & 0.36 & 0.37 & 0.01 & 0.36 & 0.31 & -0.05 & 0.38 & 0.4 & 0.02 & 0.43 & 0.33 & -0.09 \\
\hline Theil index & 0.22 & 0.23 & 0.01 & 0.32 & 0.2 & -0.12 & 0.25 & 0.28 & 0.03 & 0.44 & 0.2 & -0.22 \\
\hline Number of Observations & 1848 & 2315 & & 1315 & 2221 & & 1848 & 2315 & & 1315 & 2221 & \\
\hline
\end{tabular}


Table 3. Oaxaca Decomposition of log Wage: 2002-2007

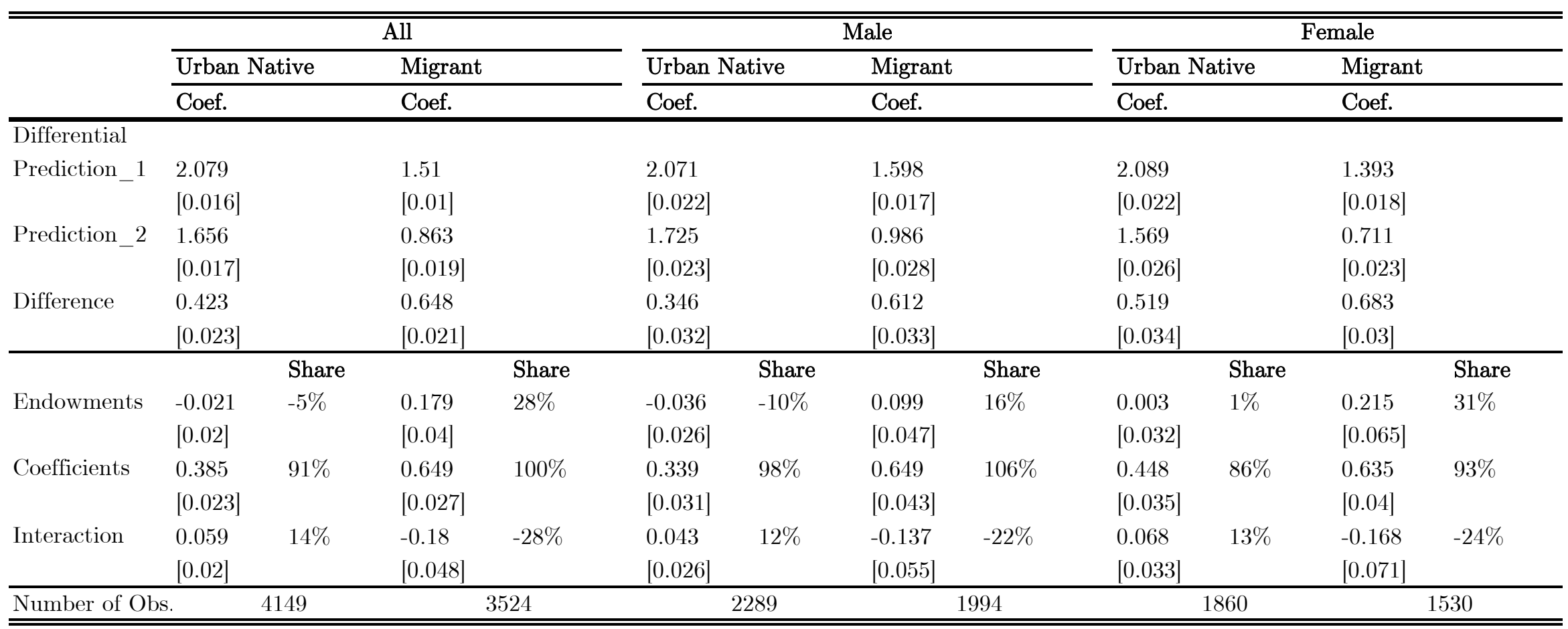

Note: Numbers inside square brackets are standard errors;

$* * *, * *, *$ represent significant at $1 \% .5 \%$ and $10 \%$ level, respectively. 
Table 4. Oaxaca Decomposition of log Wage from 2002 to 2007

\begin{tabular}{|c|c|c|c|c|c|c|c|}
\hline & \multicolumn{2}{|c|}{ All } & \multicolumn{2}{|c|}{ Male } & \multicolumn{2}{|c|}{ Female } \\
\hline & & $\begin{array}{l}\text { Urban } \\
\text { Native }\end{array}$ & Migrant & $\begin{array}{l}\text { Urban } \\
\text { Native }\end{array}$ & Migrant & $\begin{array}{l}\text { Urban } \\
\text { Native }\end{array}$ & Migrant \\
\hline Endowment & total & $-4.93 \%$ & $27.59 \%$ & $-10.53 \%$ & $16.24 \%$ & $0.67 \%$ & $31.53 \%$ \\
\hline & Human capital & $3.69 \%$ & $6.19 \%$ & $4.59 \%$ & $-0.53 \%$ & $3.07 \%$ & $12.43 \%$ \\
\hline & Education & $8.27 \%$ & $5.32 \%$ & $8.94 \%$ & $2.59 \%$ & $7.67 \%$ & $7.01 \%$ \\
\hline & Age & $-6.61 \%$ & $0.27 \%$ & $-7.26 \%$ & $-3.62 \%$ & $-6.06 \%$ & $5.20 \%$ \\
\hline & Health & $2.03 \%$ & $0.60 \%$ & $2.91 \%$ & $0.50 \%$ & $1.46 \%$ & $0.22 \%$ \\
\hline & Discrimination & $-0.17 \%$ & $-0.71 \%$ & $-0.06 \%$ & $-1.26 \%$ & $-0.04 \%$ & $-0.30 \%$ \\
\hline & Married & $-0.02 \%$ & $-0.38 \%$ & $-0.10 \%$ & $0.48 \%$ & $0.00 \%$ & $-0.38 \%$ \\
\hline & Gender & $-0.17 \%$ & $0.62 \%$ & & & & \\
\hline & Minority & $0.02 \%$ & $-0.95 \%$ & $0.04 \%$ & $-1.74 \%$ & $-0.04 \%$ & $0.08 \%$ \\
\hline & Segmentation & $-8.47 \%$ & $29.06 \%$ & $-15.07 \%$ & $17.98 \%$ & $-2.37 \%$ & $19.28 \%$ \\
\hline & Contract & $3.80 \%$ & $-0.88 \%$ & $-1.97 \%$ & $1.41 \%$ & $9.07 \%$ & $-6.24 \%$ \\
\hline & Ownership & $-1.95 \%$ & $23.30 \%$ & $-2.52 \%$ & $21.43 \%$ & $-1.79 \%$ & $23.50 \%$ \\
\hline & Industry & $0.52 \%$ & $2.14 \%$ & $-2.35 \%$ & $1.94 \%$ & $2.85 \%$ & $-0.29 \%$ \\
\hline & City & $-10.84 \%$ & $-1.99 \%$ & $-8.23 \%$ & $-6.80 \%$ & $-12.50 \%$ & $2.31 \%$ \\
\hline Coefficient $t$ & total & $91.00 \%$ & $100.20 \%$ & $98.09 \%$ & $106.10 \%$ & $86.26 \%$ & $93.09 \%$ \\
\hline & Human capital & $-264.00 \%$ & $72.71 \%$ & $-315.19 \%$ & $4.91 \%$ & $-105.47 \%$ & $165.11 \%$ \\
\hline & Education & $-87 \%$ & $9.68 \%$ & $-103.78 \%$ & $9.62 \%$ & $-70.60 \%$ & $12.71 \%$ \\
\hline & Age & $-198.23 \%$ & $64.28 \%$ & $-264.12 \%$ & $-14.75 \%$ & $-36.99 \%$ & $153.68 \%$ \\
\hline & Health & $20.56 \%$ & $-1.25 \%$ & $46.60 \%$ & $-1.03 \%$ & $2.12 \%$ & $-1.28 \%$ \\
\hline & Discrimination & $15.81 \%$ & $-1.17 \%$ & $-0.09 \%$ & $-2.66 \%$ & $30.89 \%$ & $-11.79 \%$ \\
\hline & Married & $23.93 \%$ & $-1.61 \%$ & $6.02 \%$ & $8.41 \%$ & $30.94 \%$ & $-12.15 \%$ \\
\hline & Gender & $-8.11 \%$ & $1.80 \%$ & & & & \\
\hline & Minority & $-0.01 \%$ & $-1.36 \%$ & $-0.09 \%$ & $-2.66 \%$ & $-0.05 \%$ & $0.36 \%$ \\
\hline & Segmentation & $33.19 \%$ & $62.15 \%$ & $2.12 \%$ & $89.83 \%$ & $3.49 \%$ & $-19.48 \%$ \\
\hline & Contract & $23.61 \%$ & $61.15 \%$ & $-28.07 \%$ & $65.76 \%$ & $-17.90 \%$ & $15.13 \%$ \\
\hline & Ownership & $8.34 \%$ & $4.98 \%$ & $6.90 \%$ & $-0.69 \%$ & $9.47 \%$ & $7.72 \%$ \\
\hline & Industry & $-11.00 \%$ & $11.34 \%$ & $-19.74 \%$ & $17.17 \%$ & $-3.22 \%$ & $-5.26 \%$ \\
\hline & City & $12.24 \%$ & $-15.32 \%$ & $5.83 \%$ & $7.59 \%$ & $15.14 \%$ & $-37.07 \%$ \\
\hline & Constant & $353.61 \%$ & $-33.47 \%$ & $448.98 \%$ & $12.66 \%$ & $156.80 \%$ & $-34.33 \%$ \\
\hline Interaction & & $13.93 \%$ & $-27.78 \%$ & $12.44 \%$ & $-22.34 \%$ & $13.08 \%$ & $-24.62 \%$ \\
\hline Number of & Observations & 4149 & 3524 & 2289 & 1994 & 1860 & 1503 \\
\hline
\end{tabular}


Table 5. Duncan Index between Migrants and Urban Natives

\begin{tabular}{llll}
\hline \hline & 2002 & 2007 \\
\hline All & & 0.48 & 0.381 \\
\hline Gender & & & \\
& Male & 0.516 & 0.395 \\
& Female & 0.441 & 0.39 \\
\hline Age & & \\
& $16-25$ & 0.365 & 0.362 \\
& $26-35$ & 0.457 & 0.415 \\
& $36-45$ & 0.489 & 0.41 \\
& 45-55 or 60 & 0.565 & 0.422 \\
\hline Education & & & \\
& Primary school and below & 0.501 & 0.439 \\
& Middle school & 0.448 & 0.34 \\
& High school & 0.323 & 0.373 \\
& College and above & 0.451 & 0.459 \\
\hline \hline
\end{tabular}


Appendix Table 1. Descriptive Statistics of Urban and Migrants Samples

\begin{tabular}{|c|c|c|c|c|c|c|c|c|}
\hline \multirow[b]{3}{*}{ Variable } & \multicolumn{4}{|c|}{ Migrant } & \multicolumn{4}{|c|}{ Urban Native } \\
\hline & \multicolumn{2}{|c|}{2002} & \multicolumn{2}{|c|}{2007} & \multicolumn{2}{|c|}{2002} & \multicolumn{2}{|c|}{2007} \\
\hline & Mean & Std. Dev. & Mean & Std.Dev. & Mean & Std. Dev. & Mean & Std.Dev. \\
\hline Male & 0.552 & 0.497 & 0.573 & 0.495 & 0.558 & 0.497 & 0.545 & 0.498 \\
\hline Age & 34.594 & 7.596 & 32.07 & 9.318 & 40.686 & 8.925 & 38.81 & 9.303 \\
\hline Married & 0.935 & 0.247 & 0.731 & 0.444 & 0.892 & 0.31 & 0.888 & 0.315 \\
\hline Minority & 0.043 & 0.204 & 0.009 & 0.092 & 0.014 & 0.116 & 0.011 & 0.103 \\
\hline Education & 7.924 & 2.67 & 9.032 & 2.608 & 11.617 & 2.769 & 12.25 & 3.628 \\
\hline Good & 0.917 & 0.276 & 0.852 & 0.355 & 0.653 & 0.476 & 0.788 & 0.409 \\
\hline Normal & 0.074 & 0.261 & 0.133 & 0.339 & 0.31 & 0.463 & 0.197 & 0.398 \\
\hline Bad & 0.009 & 0.095 & 0.015 & 0.123 & 0.037 & 0.188 & 0.015 & 0.12 \\
\hline Permanent & 0.005 & 0.073 & 0.058 & 0.234 & 0.425 & 0.494 & 0.368 & 0.482 \\
\hline Long term temporary & 0.045 & 0.207 & 0.253 & 0.435 & 0.261 & 0.439 & 0.396 & 0.489 \\
\hline Short term temporary or no contract & 0.258 & 0.438 & 0.317 & 0.465 & 0.239 & 0.426 & 0.157 & 0.364 \\
\hline Self-employed & 0.672 & 0.47 & 0.354 & 0.478 & 0.054 & 0.225 & 0.074 & 0.263 \\
\hline Others & 0.02 & 0.139 & 0.018 & 0.131 & 0.022 & 0.146 & 0.005 & 0.072 \\
\hline Mineral ,Manufactory and Construction & 0.147 & 0.354 & 0.224 & 0.417 & 0.328 & 0.47 & 0.234 & 0.423 \\
\hline Electricity, Gas, Transportation and IT & 0.033 & 0.18 & 0.041 & 0.198 & 0.11 & 0.313 & 0.164 & 0.371 \\
\hline Sales and Hotel & 0.468 & 0.499 & 0.519 & 0.5 & 0.131 & 0.338 & 0.156 & 0.363 \\
\hline Finance, Estate, Health and Education & 0.049 & 0.215 & 0.052 & 0.221 & 0.184 & 0.388 & 0.198 & 0.398 \\
\hline Service & 0.244 & 0.43 & 0.164 & 0.37 & 0.139 & 0.346 & 0.162 & 0.369 \\
\hline Government and Public Administration & 0.059 & 0.236 & 0.002 & 0.042 & 0.107 & 0.309 & 0.086 & 0.281 \\
\hline State Owned and State Controlled & 0.078 & 0.268 & 0.045 & 0.206 & 0.345 & 0.476 & 0.18 & 0.385 \\
\hline Collective & 0.041 & 0.199 & 0.01 & 0.099 & 0.063 & 0.243 & 0.023 & 0.15 \\
\hline Private & 0.076 & 0.265 & 0.298 & 0.457 & 0.046 & 0.21 & 0.107 & 0.309 \\
\hline Individual & 0.729 & 0.445 & 0.463 & 0.499 & 0.048 & 0.214 & 0.123 & 0.328 \\
\hline Foreign and Joint Venture & 0.006 & 0.078 & 0.09 & 0.286 & 0.035 & 0.183 & 0.051 & 0.22 \\
\hline Other Shared & 0.022 & 0.147 & 0.06 & 0.237 & 0.074 & 0.262 & 0.096 & 0.295 \\
\hline Others & 0.049 & 0.215 & 0.035 & 0.183 & 0.287 & 0.453 & 0.338 & 0.473 \\
\hline Wuxi & 0.179 & 0.383 & 0.112 & 0.316 & 0.095 & 0.294 & 0.087 & 0.282 \\
\hline Hefei & 0.132 & 0.339 & 0.141 & 0.348 & 0.08 & 0.271 & 0.209 & 0.407 \\
\hline Zhengzhou & 0.116 & 0.321 & 0.158 & 0.365 & 0.124 & 0.33 & 0.128 & 0.334 \\
\hline Wuhan & 0.139 & 0.346 & 0.141 & 0.348 & 0.174 & 0.379 & 0.148 & 0.355 \\
\hline Guangzhou & 0.138 & 0.345 & 0.148 & 0.355 & 0.174 & 0.379 & 0.149 & 0.356 \\
\hline Chongqing & 0.148 & 0.356 & 0.172 & 0.377 & 0.221 & 0.415 & 0.168 & 0.374 \\
\hline Chengdu & 0.147 & 0.354 & 0.127 & 0.334 & 0.133 & 0.339 & 0.111 & 0.314 \\
\hline Monthly wage & 873.8 & 1186.8 & 1410 & 1207 & 1172.8 & 876.5 & 1883 & 1471 \\
\hline Hourly wage & 3.233 & 5.13 & 5.488 & 4.494 & 6.763 & 5.418 & 10.5 & 9.993 \\
\hline Number of Observations & 18 & 848 & 23 & 315 & & 315 & & 221 \\
\hline
\end{tabular}


Appendix Table 2. Descriptive Statistics of Rural Samples

\begin{tabular}{|c|c|c|c|c|c|c|c|c|}
\hline \multirow[b]{3}{*}{ Variable } & \multicolumn{4}{|c|}{ Migrant } & \multicolumn{4}{|c|}{ Non Migrant } \\
\hline & \multicolumn{2}{|c|}{2002} & \multicolumn{2}{|c|}{2007} & \multicolumn{2}{|c|}{2002} & \multicolumn{2}{|c|}{2007} \\
\hline & Mean & Std. Dev. & Mean & Std.Dev. & Mean & Std. Dev. & Mean & Std.Dev. \\
\hline Male & 0.667 & 0.471 & 0.632 & 0.482 & 0.494 & 0.5 & 0.523 & 0.499 \\
\hline Age & 30.228 & 10.084 & 28.642 & 9.002 & 37.429 & 12.587 & 40.468 & 11.531 \\
\hline Married & 0.57 & 0.495 & 0.573 & 0.495 & 0.771 & 0.42 & 0.857 & 0.35 \\
\hline Migration experience & 0.389 & 0.488 & 0.97 & 0.171 & 0.112 & 0.316 & 0.195 & 0.396 \\
\hline Household size & 4.433 & 1.215 & 3.911 & 1.206 & 4.282 & 1.192 & 3.305 & 1.127 \\
\hline Child between 0-6 & 0.181 & 0.385 & 0.021 & 0.144 & 0.16 & 0.367 & 0.015 & 0.123 \\
\hline Child between 7-16 & 0.459 & 0.498 & 0.067 & 0.25 & 0.503 & 0.5 & 0.068 & 0.251 \\
\hline Schooling year & 8.29 & 2.26 & 8.691 & 2.217 & 7.331 & 2.897 & 7.677 & 2.558 \\
\hline \multicolumn{9}{|l|}{ Schooling level } \\
\hline Below primary school & 0.061 & 0.239 & 0.032 & 0.175 & 0.166 & 0.372 & 0.092 & 0.289 \\
\hline Primary school & 0.186 & 0.389 & 0.179 & 0.383 & 0.274 & 0.446 & 0.33 & 0.47 \\
\hline Middle school & 0.608 & 0.488 & 0.635 & 0.481 & 0.445 & 0.497 & 0.461 & 0.498 \\
\hline High school & 0.145 & 0.352 & 0.154 & 0.361 & 0.116 & 0.32 & 0.118 & 0.322 \\
\hline Revolution area & 0.311 & 0.463 & 0.333 & 0.471 & 0.231 & 0.422 & 0.276 & 0.447 \\
\hline Minority village & 0.005 & 0.069 & 0.014 & 0.117 & 0.009 & 0.093 & 0.013 & 0.114 \\
\hline Suburb village & 0.046 & 0.211 & 0.025 & 0.156 & 0.058 & 0.234 & 0.072 & 0.258 \\
\hline Road access & 0.969 & 0.173 & 0.989 & 0.106 & 0.969 & 0.173 & 0.993 & 0.084 \\
\hline Telephone access & 0.991 & 0.093 & 0.999 & 0.032 & 0.989 & 0.105 & 0.999 & 0.033 \\
\hline \multicolumn{9}{|l|}{ Distance to the city } \\
\hline Less than $2 \mathrm{~km}$ & 0.02 & 0.14 & 0.02 & 0.14 & 0.029 & 0.169 & 0.036 & 0.185 \\
\hline $2-5 \mathrm{~km}$ & 0.081 & 0.273 & 0.038 & 0.191 & 0.065 & 0.246 & 0.05 & 0.218 \\
\hline $5-10 \mathrm{~km}$ & 0.135 & 0.342 & 0.081 & 0.273 & 0.126 & 0.332 & 0.105 & 0.306 \\
\hline $10-20 \mathrm{~km}$ & 0.282 & 0.45 & 0.242 & 0.428 & 0.288 & 0.453 & 0.299 & 0.458 \\
\hline Over $20 \mathrm{~km}$ & 0.482 & 0.5 & 0.619 & 0.486 & 0.491 & 0.5 & 0.511 & 0.5 \\
\hline \multicolumn{9}{|l|}{ Geographic area } \\
\hline Plain area & 0.494 & 0.5 & 0.369 & 0.483 & 0.561 & 0.496 & 0.449 & 0.497 \\
\hline Hill area & 0.367 & 0.482 & 0.447 & 0.497 & 0.3 & 0.458 & 0.399 & 0.49 \\
\hline Mountain area & 0.139 & 0.346 & 0.184 & 0.388 & 0.14 & 0.347 & 0.151 & 0.358 \\
\hline \multicolumn{9}{|l|}{ Province } \\
\hline Hebei & 0.046 & 0.211 & 0.021 & 0.142 & 0.098 & 0.298 & 0.073 & 0.26 \\
\hline Jiangsu & 0.109 & 0.312 & 0.105 & 0.307 & 0.1 & 0.3 & 0.121 & 0.326 \\
\hline Zhejiang & 0.104 & 0.306 & 0.036 & 0.187 & 0.123 & 0.328 & 0.133 & 0.34 \\
\hline Anhui & 0.171 & 0.376 & 0.156 & 0.363 & 0.099 & 0.299 & 0.092 & 0.288 \\
\hline Henan & 0.119 & 0.324 & 0.101 & 0.302 & 0.141 & 0.348 & 0.132 & 0.338 \\
\hline Hubei & 0.104 & 0.305 & 0.184 & 0.387 & 0.133 & 0.34 & 0.127 & 0.333 \\
\hline Guangdong & 0.164 & 0.37 & 0.178 & 0.382 & 0.151 & 0.358 & 0.146 & 0.353 \\
\hline Chongqing & 0.048 & 0.214 & 0.061 & 0.239 & 0.042 & 0.201 & 0.055 & 0.229 \\
\hline Sichuan & 0.135 & 0.341 & 0.158 & 0.365 & 0.112 & 0.316 & 0.122 & 0.327 \\
\hline Number of Observations & \multicolumn{2}{|c|}{2303} & \multicolumn{2}{|c|}{4947} & \multicolumn{2}{|c|}{8830} & \multicolumn{2}{|c|}{14697} \\
\hline
\end{tabular}


Appendix Table 3. Migration Decision in 2002 and 2007

\begin{tabular}{|c|c|c|c|c|c|c|c|c|c|c|c|c|}
\hline & \multicolumn{4}{|c|}{ All } & \multicolumn{4}{|c|}{ Male } & \multicolumn{4}{|c|}{$\overline{\text { Female }}$} \\
\hline & \multicolumn{2}{|l|}{2002} & \multicolumn{2}{|l|}{2007} & \multicolumn{2}{|l|}{2002} & \multicolumn{2}{|l|}{2007} & \multicolumn{2}{|l|}{2002} & \multicolumn{2}{|l|}{2007} \\
\hline & Coef. & $\begin{array}{c}\text { Marginal } \\
\text { Effect }\end{array}$ & Coef. & $\begin{array}{c}\text { Marginal } \\
\text { Effect }\end{array}$ & Coef. & $\begin{array}{c}\text { Marginal } \\
\text { Effect }\end{array}$ & Coef. & $\begin{array}{c}\text { Marginal } \\
\text { Effect }\end{array}$ & Coef. & $\begin{array}{c}\text { Marginal } \\
\text { Effect }\end{array}$ & Coef. & $\begin{array}{c}\text { Marginal } \\
\text { Effect }\end{array}$ \\
\hline \multirow[t]{2}{*}{ Male } & $0.747^{* * *}$ & $0.095^{* * *}$ & $0.367^{* * *}$ & $0.019^{* * *}$ & & & & & & & & \\
\hline & {$[0.056]$} & {$[0.007]$} & {$[0.054]$} & {$[0.003]$} & & & & & & & & \\
\hline \multirow[t]{2}{*}{ Age } & $0.268^{* * *}$ & $0.035^{* * *}$ & $0.106^{* * *}$ & $0.006^{* * *}$ & $0.305^{* * *}$ & $0.051^{* * *}$ & $0.120 * * *$ & $0.009 * * *$ & $0.335^{* * *}$ & $0.023^{* * *}$ & $0.104^{* * *}$ & $0.004^{* * *}$ \\
\hline & {$[0.021]$} & {$[0.003]$} & {$[0.021]$} & {$[0.001]$} & {$[0.026]$} & {$[0.004]$} & {$[0.026]$} & {$[0.002]$} & {$[0.043]$} & {$[0.003]$} & {$[0.040]$} & {$[0.001]$} \\
\hline \multirow[t]{2}{*}{ Age squre } & $-0.004^{* * *}$ & $-0.001 * * *$ & $-0.002^{* * *}$ & $-0.000 * * *$ & $-0.005^{* * *}$ & $-0.001^{* * *}$ & $-0.003 * * *$ & $-0.000 * * *$ & $-0.006 * * *$ & $-0.000 * * *$ & $-0.002 * * *$ & $-0.000 * * *$ \\
\hline & {$[0.000]$} & {$[0.000]$} & {$[0.000]$} & {$[0.000]$} & {$[0.000]$} & {$[0.000]$} & {$[0.000]$} & {$[0.000]$} & {$[0.001]$} & {$[0.000]$} & {$[0.001]$} & {$[0.000]$} \\
\hline \multirow[t]{2}{*}{ Married } & $-0.815^{* * *}$ & $-0.119 * * *$ & $-0.592^{* * *}$ & $-0.037^{* * *}$ & $-0.377^{* * *}$ & $-0.066^{* * *}$ & $-0.404 * * *$ & $-0.033 * * *$ & $-1.617^{* * *}$ & $-0.162^{* * *}$ & $-0.918^{* * *}$ & $-0.041^{* * *}$ \\
\hline & {$[0.102]$} & {$[0.017]$} & {$[0.085]$} & {$[0.006]$} & {$[0.126]$} & {$[0.023]$} & {$[0.110]$} & {$[0.010]$} & {$[0.178]$} & {$[0.025]$} & [0.139] & [0.009] \\
\hline \multirow[t]{2}{*}{ Migration Experience } & $1.375^{* * *}$ & $0.235^{* * *}$ & $4.412^{* * *}$ & $0.461^{* * *}$ & $1.068^{* * *}$ & $0.208^{* * *}$ & 4. $362 * * *$ & $0.476 * * *$ & $1.822^{* * *}$ & $0.226^{* * *}$ & $4.457^{* * *}$ & $0.428 * * *$ \\
\hline & {$[0.061]$} & {$[0.013]$} & {$[0.088]$} & {$[0.008]$} & {$[0.075]$} & {$[0.016]$} & {$[0.116]$} & {$[0.010]$} & {$[0.111]$} & {$[0.022]$} & {$[0.137]$} & {$[0.016]$} \\
\hline \multirow[t]{2}{*}{ Child between 0-6 } & -0.066 & -0.008 & -0.112 & -0.006 & 0.072 & 0.012 & 0.041 & 0.003 & $-0.413^{* * *}$ & $-0.026^{* * *}$ & -0.356 & -0.012 \\
\hline & {$[0.085]$} & {$[0.011]$} & {$[0.174]$} & {$[0.009]$} & {$[0.105]$} & {$[0.018]$} & {$[0.232]$} & {$[0.017]$} & {$[0.153]$} & {$[0.008]$} & {$[0.271]$} & {$[0.009]$} \\
\hline \multirow[t]{2}{*}{ Child between 7-16 } & $-0.290 * * *$ & $-0.037 * * *$ & $-0.265^{* * *}$ & $-0.014^{* * *}$ & $-0.263^{* * *}$ & $-0.044^{* * *}$ & $-0.334 * * *$ & $-0.025 * * *$ & $-0.526^{* * *}$ & $-0.037 * * *$ & -0.19 & -0.006 \\
\hline & {$[0.059]$} & {$[0.008]$} & {$[0.090]$} & {$[0.005]$} & {$[0.074]$} & {$[0.012]$} & {$[0.116]$} & {$[0.009]$} & {$[0.103]$} & {$[0.008]$} & {$[0.147]$} & {$[0.005]$} \\
\hline \multirow[t]{2}{*}{ Household size } & $0.126^{* * *}$ & $0.016^{* * *}$ & $0.289^{* * *}$ & $0.016^{* * *}$ & 0.044 & 0.007 & $0.282 * * *$ & $0.021 * * *$ & $0.225^{* * *}$ & $0.016^{* * *}$ & $0.325^{* * *}$ & $0.011^{* * *}$ \\
\hline & {$[0.026]$} & {$[0.003]$} & {$[0.025]$} & {$[0.001]$} & {$[0.032]$} & [0.005] & {$[0.031]$} & {$[0.003]$} & {$[0.045]$} & [0.003] & [0.041] & {$[0.002]$} \\
\hline \multirow[t]{2}{*}{ Primary school } & $0.287^{* *}$ & $0.039 * *$ & 0.098 & 0.005 & 0.006 & 0.001 & -0.144 & -0.01 & 0.197 & 0.014 & 0.277 & 0.01 \\
\hline & {$[0.113]$} & {$[0.016]$} & {$[0.134]$} & {$[0.007]$} & {$[0.154]$} & {$[0.026]$} & {$[0.184]$} & {$[0.013]$} & {$[0.183]$} & {$[0.014]$} & [0.198] & {$[0.007]$} \\
\hline \multirow[t]{2}{*}{ Middle school } & $0.428^{* * *}$ & $0.056^{* * *}$ & 0.107 & 0.006 & 0.089 & 0.015 & -0.224 & -0.017 & $0.301^{*}$ & $0.021^{*}$ & $0.408^{* *}$ & $0.014^{* *}$ \\
\hline & {$[0.108]$} & {$[0.014]$} & {$[0.128]$} & {$[0.007]$} & {$[0.147]$} & {$[0.024]$} & {$[0.177]$} & {$[0.013]$} & {$[0.177]$} & {$[0.013]$} & [0.191] & {$[0.007]$} \\
\hline \multirow[t]{2}{*}{ High school } & 0.005 & 0.001 & 0.051 & 0.003 & -0.265 & $-0.042^{*}$ & -0.187 & -0.013 & -0.353 & $-0.022^{*}$ & 0.122 & 0.004 \\
\hline & {$[0.128]$} & {$[0.017]$} & {$[0.143]$} & {$[0.008]$} & {$[0.166]$} & {$[0.025]$} & {$[0.191]$} & {$[0.013]$} & {$[0.225]$} & {$[0.012]$} & {$[0.226]$} & {$[0.008]$} \\
\hline \multirow[t]{2}{*}{ Plain area } & $-0.225^{* * *}$ & $-0.029 * * *$ & -0.064 & -0.003 & $-0.271^{* * *}$ & $-0.046^{* * *}$ & 0.013 & 0.001 & $-0.195^{*}$ & -0.014 & $-0.214^{* *}$ & $-0.007^{* *}$ \\
\hline & {$[0.067]$} & {$[0.009]$} & {$[0.064]$} & {$[0.003]$} & {$[0.083]$} & {$[0.014]$} & {$[0.081]$} & {$[0.006]$} & {$[0.118]$} & {$[0.008]$} & {$[0.106]$} & {$[0.004]$} \\
\hline \multirow[t]{2}{*}{ Mountain area } & $-0.335^{* * *}$ & $-0.040 * * *$ & $0.188^{* *}$ & $0.011^{* *}$ & $-0.234^{* *}$ & $-0.037 * *$ & 0.161 & 0.012 & $-0.582^{* * *}$ & $-0.034^{* * *}$ & $0.256^{*}$ & $0.009^{*}$ \\
\hline & {$[0.092]$} & {$[0.010]$} & {$[0.081]$} & {$[0.005]$} & {$[0.116]$} & {$[0.018]$} & {$[0.104]$} & {$[0.008]$} & {$[0.159]$} & {$[0.008]$} & {$[0.132]$} & {$[0.005]$} \\
\hline \multirow[t]{2}{*}{ Revolution area } & $0.573^{* * *}$ & $0.081^{* * *}$ & $0.351^{* * *}$ & $0.020^{* * *}$ & $0.596^{* * *}$ & $0.108^{* * *}$ & $0.325 * * *$ & $0.026 * * *$ & $0.645^{* * *}$ & $0.052^{* * *}$ & $0.392^{* * *}$ & $0.014^{* * *}$ \\
\hline & {$[0.076]$} & {$[0.012]$} & {$[0.066]$} & {$[0.004]$} & {$[0.096]$} & {$[0.019]$} & {$[0.084]$} & {$[0.007]$} & {$[0.129]$} & {$[0.012]$} & {$[0.109]$} & {$[0.004]$} \\
\hline
\end{tabular}


Appendix Table 3. Migration Decision in 2002 and 2007 (Cont.)

\begin{tabular}{|c|c|c|c|c|c|c|c|c|c|c|c|c|}
\hline & \multicolumn{4}{|c|}{ All } & \multicolumn{4}{|c|}{ Male } & \multicolumn{4}{|c|}{ Female } \\
\hline & \multicolumn{2}{|c|}{2002} & \multicolumn{2}{|c|}{2007} & \multicolumn{2}{|c|}{2002} & \multicolumn{2}{|l|}{2007} & \multicolumn{2}{|l|}{2002} & \multicolumn{2}{|c|}{2007} \\
\hline & Coef. & Marginal & Coef. & Marginal & Coef. & Marginal & Coef. & Marginal & Coef. & Marginal & Coef. & Marginal \\
\hline \multirow[t]{2}{*}{ Minority village } & -0.333 & -0.038 & $1.127^{* * *}$ & $0.099 * * *$ & -0.246 & -0.038 & $0.902 * * *$ & $0.096 * *$ & -0.794 & -0.04 & $1.594^{* * *}$ & $0.115^{* *}$ \\
\hline & {$[0.365]$} & [0.037] & {$[0.246]$} & {$[0.032]$} & {$[0.430]$} & {$[0.062]$} & {$[0.300]$} & {$[0.043]$} & {$[0.746]$} & {$[0.026]$} & {$[0.430]$} & {$[0.054]$} \\
\hline \multirow[t]{2}{*}{ Surburb village } & $0.355^{* *}$ & $0.051^{* *}$ & $-0.258^{*}$ & $-0.013^{*}$ & $0.332^{*}$ & $0.060^{*}$ & -0.226 & -0.015 & $0.443^{*}$ & 0.036 & -0.288 & -0.009 \\
\hline & {$[0.140]$} & {$[0.022]$} & {$[0.156]$} & {$[0.007]$} & {$[0.179]$} & {$[0.035]$} & {$[0.200]$} & {$[0.012]$} & {$[0.232]$} & {$[0.022]$} & {$[0.252]$} & {$[0.007]$} \\
\hline \multirow[t]{2}{*}{ Road access } & -0.062 & -0.008 & -0.325 & -0.02 & -0.032 & -0.005 & -0.446 & -0.04 & -0.35 & -0.028 & -0.169 & -0.006 \\
\hline & {$[0.155]$} & {$[0.021]$} & {$[0.244]$} & {$[0.017]$} & {$[0.184]$} & {$[0.031]$} & {$[0.308]$} & {$[0.032]$} & {$[0.290]$} & {$[0.026]$} & {$[0.418]$} & {$[0.017]$} \\
\hline \multirow[t]{2}{*}{ Telephone access } & 0.025 & 0.003 & $1.034^{*}$ & $0.036^{* * *}$ & 0.275 & 0.042 & 1. 057 & $0.051 * *$ & -0.54 & -0.047 & 0.979 & $0.022^{*}$ \\
\hline & {$[0.290]$} & {$[0.037]$} & {$[0.627]$} & {$[0.013]$} & {$[0.349]$} & {$[0.049]$} & {$[0.836]$} & {$[0.024]$} & {$[0.513]$} & {$[0.055]$} & {$[0.958]$} & {$[0.013]$} \\
\hline \multicolumn{13}{|c|}{ Distance to the city } \\
\hline \multirow[t]{2}{*}{$2-5 \mathrm{~km}$} & $0.796^{* * *}$ & $0.128^{* * *}$ & $-0.337^{*}$ & $-0.016^{*}$ & $0.667^{* * *}$ & $0.129^{* *}$ & $-0.632 * *$ & $-0.037 * * *$ & $1.203^{* * *}$ & $0.130^{* *}$ & 0.056 & 0.002 \\
\hline & {$[0.212]$} & {$[0.041]$} & {$[0.199]$} & {$[0.008]$} & {$[0.255]$} & {$[0.056]$} & {$[0.258]$} & {$[0.012]$} & {$[0.410]$} & {$[0.063]$} & {$[0.321]$} & {$[0.011]$} \\
\hline \multirow[t]{2}{*}{$5-10 \mathrm{~km}$} & $0.727^{* * *}$ & $0.112^{* * *}$ & -0.206 & -0.01 & $0.512^{* *}$ & $0.095^{*}$ & $-0.494 * *$ & $-0.031 * *$ & $1.227^{* * *}$ & $0.126^{* *}$ & 0.187 & 0.007 \\
\hline & {$[0.202]$} & {$[0.036]$} & {$[0.185]$} & {$[0.009]$} & {$[0.243]$} & {$[0.049]$} & {$[0.241]$} & {$[0.013]$} & {$[0.393]$} & {$[0.056]$} & {$[0.298]$} & {$[0.012]$} \\
\hline \multirow[t]{2}{*}{$10-20 \mathrm{~km}$} & $0.618^{* * *}$ & $0.087^{* * *}$ & 0.021 & 0.001 & $0.459^{*}$ & $0.081^{*}$ & -0.29 & -0.02 & $1.015^{* * *}$ & $0.086^{* *}$ & $0.495^{*}$ & 0.019 \\
\hline & [0.198] & {$[0.030]$} & {$[0.176]$} & {$[0.010]$} & {$[0.236]$} & {$[0.044]$} & {$[0.228]$} & {$[0.015]$} & {$[0.387]$} & {$[0.040]$} & {$[0.284]$} & {$[0.012]$} \\
\hline \multirow[t]{2}{*}{ Over $20 \mathrm{~km}$} & $0.457^{* *}$ & $0.059^{* *}$ & 0.211 & 0.011 & 0.303 & 0.051 & -0.02 & -0.001 & $0.911^{* *}$ & $0.065^{* *}$ & $0.547^{* *}$ & $0.018^{*}$ \\
\hline & {$[0.194]$} & {$[0.025]$} & {$[0.173]$} & {$[0.009]$} & {$[0.232]$} & {$[0.039]$} & {$[0.225]$} & {$[0.017]$} & {$[0.380]$} & {$[0.028]$} & {$[0.279]$} & {$[0.010]$} \\
\hline
\end{tabular}

Other controls: Province Dummies

\begin{tabular}{|c|c|c|c|c|c|c|c|c|c|c|c|c|}
\hline Number of Obs. & 11104 & 11104 & 19644 & 19644 & 5885 & 5885 & 10817 & 10817 & 5219 & 5219 & 8827 & 8827 \\
\hline
\end{tabular}

Note:

Numbers inside square brackets are standard errors;

$* * *, * *, *$ represent significant at $1 \% .5 \%$ and $10 \%$ level, respectively. 
Appendix Table 4. Wage Equations of Natives and Migrants in 2002 and 2007

\begin{tabular}{|c|c|c|c|c|c|c|c|c|c|c|c|c|}
\hline & \multicolumn{4}{|c|}{$\begin{array}{lc} & \text { All }\end{array}$} & \multicolumn{4}{|c|}{$\begin{array}{ll} & \text { Male }\end{array}$} & \multicolumn{4}{|c|}{$\begin{array}{ll}\text { Female } \\
\end{array}$} \\
\hline & \multicolumn{2}{|c|}{ Urban Resident } & \multicolumn{2}{|c|}{ Migrant } & \multicolumn{2}{|c|}{ Urban Resident } & \multicolumn{2}{|c|}{ Migrant } & \multicolumn{2}{|c|}{ Urban Resident } & \multicolumn{2}{|c|}{ Migrant } \\
\hline & 2002 & 2007 & 2002 & 2007 & 2002 & 2007 & 2002 & 2007 & 2002 & 2007 & 2002 & 2007 \\
\hline \multirow[t]{2}{*}{ Male } & $0.059^{* *}$ & -0.002 & $0.182^{* * *}$ & $0.203^{* * *}$ & & & & & & & & \\
\hline & {$[0.028]$} & {$[0.027]$} & {$[0.035]$} & {$[0.024]$} & & & & & & & & \\
\hline \multirow[t]{2}{*}{ Education } & $0.055^{* * *}$ & $0.024^{* * *}$ & $0.029^{* * *}$ & $0.036^{* * *}$ & $0.051^{* * *}$ & $0.020^{* * *}$ & $0.020^{*}$ & $0.027^{* * *}$ & $0.060^{* * *}$ & $0.029^{* * *}$ & $0.033^{* * *}$ & $0.044^{* * *}$ \\
\hline & {$[0.005]$} & {$[0.004]$} & {$[0.007]$} & {$[0.005]$} & {$[0.007]$} & {$[0.005]$} & {$[0.011]$} & {$[0.007]$} & {$[0.008]$} & {$[0.006]$} & {$[0.009]$} & {$[0.007]$} \\
\hline \multirow[t]{2}{*}{ Age } & $0.043^{* * *}$ & 0.019 & 0.009 & $0.031^{* * *}$ & $0.053^{* *}$ & 0.023 & 0.042 & $0.039^{* * *}$ & 0.022 & $0.037^{*}$ & -0.023 & $0.031^{* *}$ \\
\hline & {$[0.015]$} & {$[0.013]$} & {$[0.018]$} & {$[0.010]$} & {$[0.021]$} & {$[0.018]$} & {$[0.026]$} & {$[0.014]$} & {$[0.026]$} & {$[0.020]$} & {$[0.026]$} & {$[0.015]$} \\
\hline \multirow[t]{2}{*}{ Age squared } & $-0.000^{* *}$ & $-0.000^{*}$ & 0 & $-0.000^{* * *}$ & $-0.001^{* *}$ & 0 & $-0.001^{*}$ & $-0.001^{* * *}$ & 0 & $-0.001^{* *}$ & 0 & $-0.000^{* *}$ \\
\hline & {$[0.000]$} & {$[0.000]$} & {$[0.000]$} & {$[0.000]$} & {$[0.000]$} & {$[0.000]$} & {$[0.000]$} & {$[0.000]$} & {$[0.000]$} & {$[0.000]$} & {$[0.000]$} & {$[0.000]$} \\
\hline \multirow[t]{2}{*}{ Minority } & -0.033 & -0.034 & $0.174^{* *}$ & -0.027 & -0.094 & -0.12 & $0.278^{* *}$ & -0.069 & 0.042 & 0.026 & -0.02 & 0.044 \\
\hline & {$[0.115]$} & {$[0.126]$} & [0.084] & {$[0.122]$} & {$[0.170]$} & {$[0.181]$} & {$[0.120]$} & {$[0.175]$} & [0.157] & {$[0.174]$} & [0.115] & [0.165] \\
\hline \multirow[t]{2}{*}{ Married } & 0.019 & $0.132^{* *}$ & 0.011 & 0.001 & 0.036 & 0.059 & -0.016 & 0.057 & 0.007 & $0.187^{* *}$ & 0.005 & -0.077 \\
\hline & {$[0.068]$} & {$[0.054]$} & {$[0.088]$} & {$[0.039]$} & {$[0.095]$} & {$[0.078]$} & {$[0.122]$} & {$[0.056]$} & [0.101] & {$[0.075]$} & {$[0.126]$} & {$[0.052]$} \\
\hline \multirow[t]{2}{*}{ Normal } & 0.074 & 0.183 & 0.121 & -0.03 & 0.099 & $0.292^{*}$ & -0.199 & -0.028 & 0.04 & 0.073 & $0.464^{* *}$ & -0.034 \\
\hline & {$[0.073]$} & {$[0.113]$} & {$[0.171]$} & {$[0.034]$} & {$[0.114]$} & {$[0.168]$} & {$[0.264]$} & {$[0.049]$} & {$[0.096]$} & {$[0.151]$} & {$[0.212]$} & {$[0.046]$} \\
\hline \multirow[t]{2}{*}{ Good } & $0.125^{*}$ & $0.207^{*}$ & 0.049 & -0.14 & 0.166 & $0.317^{*}$ & -0.224 & -0.058 & 0.083 & 0.084 & $0.351^{*}$ & -0.161 \\
\hline & {$[0.072]$} & {$[0.110]$} & {$[0.162]$} & {$[0.092]$} & {$[0.112]$} & {$[0.165]$} & {$[0.249]$} & {$[0.144]$} & [0.093] & {$[0.148]$} & {$[0.201]$} & {$[0.114]$} \\
\hline \multirow[t]{2}{*}{ Long temporary } & -0.048 & $-0.239^{* * *}$ & -0.252 & 0.027 & -0.069 & $-0.231^{* * *}$ & -0.252 & -0.004 & -0.035 & $-0.246^{* * *}$ & -0.034 & 0.07 \\
\hline & {$[0.036]$} & {$[0.032]$} & {$[0.239]$} & {$[0.053]$} & {$[0.048]$} & {$[0.046]$} & {$[0.288]$} & {$[0.073]$} & {$[0.054]$} & {$[0.045]$} & {$[0.532]$} & {$[0.075]$} \\
\hline \multirow[t]{2}{*}{ Short temporary or no contract } & $-0.342^{* * *}$ & $-0.642^{* * *}$ & $-0.611^{* * *}$ & $-0.094^{*}$ & $-0.345^{* * *}$ & $-0.640^{* * *}$ & $-0.651^{* *}$ & $-0.135^{*}$ & $-0.357^{* * *}$ & $-0.649^{* * *}$ & -0.248 & -0.049 \\
\hline & {$[0.042]$} & {$[0.045]$} & {$[0.227]$} & {$[0.052]$} & {$[0.060]$} & {$[0.062]$} & {$[0.270]$} & {$[0.072]$} & {$[0.059]$} & {$[0.066]$} & {$[0.516]$} & {$[0.073]$} \\
\hline \multirow[t]{2}{*}{ Self-employed } & $-0.459^{* * *}$ & -0.046 & -0.259 & $0.104^{*}$ & $-0.292^{* * *}$ & -0.126 & -0.274 & 0.1 & $-0.683^{* * *}$ & 0.036 & 0.031 & 0.104 \\
\hline & {$[0.077]$} & [0.067] & [0.229] & {$[0.055]$} & {$[0.106]$} & [0.095] & {$[0.276]$} & {$[0.075]$} & {$[0.114]$} & {$[0.095]$} & {$[0.510]$} & {$[0.078]$} \\
\hline \multirow[t]{2}{*}{ Others } & $-0.276^{* * *}$ & -0.288 & $-0.424^{*}$ & -0.141 & 0.044 & -0.307 & $-0.569^{*}$ & -0.119 & $-0.516^{* * *}$ & -0.269 & 0.017 & -0.14 \\
\hline & {$[0.103]$} & [0.182] & {$[0.257]$} & [0.098] & [0.164] & {$[0.270]$} & {$[0.320]$} & {$[0.141]$} & {$[0.132]$} & {$[0.245]$} & {$[0.542]$} & [0.131] \\
\hline \multirow[t]{2}{*}{ Collective } & $-0.164^{* * *}$ & 0.091 & -0.005 & -0.025 & $-0.170^{*}$ & -0.027 & 0.07 & -0.009 & $-0.179^{* *}$ & $0.199^{*}$ & -0.045 & -0.101 \\
\hline & {$[0.057]$} & [0.089] & {$[0.103]$} & [0.125] & {$[0.090]$} & [0.139] & {$[0.150]$} & {$[0.183]$} & {$[0.075]$} & [0.114] & [0.138] & [0.168] \\
\hline \multirow[t]{2}{*}{ Private } & -0.042 & 0.012 & $0.363^{* * *}$ & -0.017 & 0.052 & 0.005 & $0.415^{* * *}$ & -0.032 & $-0.168^{*}$ & 0.018 & $0.260^{* *}$ & -0.045 \\
\hline & {$[0.068]$} & {$[0.048]$} & {$[0.086]$} & {$[0.058]$} & {$[0.094]$} & {$[0.070]$} & {$[0.118]$} & {$[0.075]$} & {$[0.100]$} & {$[0.067]$} & {$[0.130]$} & {$[0.096]$} \\
\hline
\end{tabular}


Appendix Table 4. Wage Equations of Natives and Migrants in 2002 and 2007 (Cont.)

\begin{tabular}{|c|c|c|c|c|c|c|c|c|c|c|c|c|}
\hline & \multicolumn{4}{|c|}{ All } & \multicolumn{4}{|c|}{ Male } & \multicolumn{4}{|c|}{ Female } \\
\hline & \multicolumn{2}{|c|}{ Urban Resident } & \multicolumn{2}{|c|}{ Migrant } & \multicolumn{2}{|c|}{ Urban Resident } & \multicolumn{2}{|c|}{ Migrant } & \multicolumn{2}{|c|}{ Urban Resident } & \multicolumn{2}{|c|}{ Migrant } \\
\hline & 2002 & 2007 & 2002 & 2007 & 2002 & 2007 & 2002 & 2007 & 2002 & 2007 & 2002 & 2007 \\
\hline \multirow[t]{2}{*}{ Individual } & $-0.170^{* *}$ & -0.076 & $-0.156^{*}$ & -0.064 & $-0.189^{*}$ & -0.028 & -0.127 & -0.05 & -0.125 & -0.126 & -0.178 & -0.126 \\
\hline & {$[0.074]$} & {$[0.055]$} & {$[0.082]$} & {$[0.060]$} & {$[0.100]$} & {$[0.077]$} & {$[0.117]$} & {$[0.078]$} & {$[0.111]$} & {$[0.079]$} & {$[0.112]$} & {$[0.098]$} \\
\hline \multirow[t]{2}{*}{ Foreign and Joint Venture } & 0.095 & $0.149^{* *}$ & 0.219 & 0.103 & 0.134 & $0.172^{*}$ & 0.176 & 0.13 & 0.039 & 0.128 & 0.269 & 0.05 \\
\hline & {$[0.075]$} & {$[0.062]$} & {$[0.223]$} & {$[0.069]$} & {$[0.098]$} & [0.091] & {$[0.310]$} & {$[0.094]$} & {$[0.120]$} & {$[0.086]$} & {$[0.320]$} & {$[0.108]$} \\
\hline \multirow[t]{2}{*}{ Other stock } & -0.085 & 0.042 & $0.261^{* *}$ & 0.069 & $-0.142^{* *}$ & -0.058 & 0.281 & 0.034 & -0.012 & $0.142^{* *}$ & 0.251 & 0.081 \\
\hline & {$[0.053]$} & [0.049] & [0.127] & {$[0.071]$} & {$[0.072]$} & {$[0.070]$} & {$[0.203]$} & {$[0.096]$} & {$[0.079]$} & {$[0.068]$} & {$[0.156]$} & [0.110] \\
\hline \multirow[t]{2}{*}{ Others } & -0.045 & -0.035 & -0.067 & -0.037 & -0.076 & -0.03 & -0.034 & 0.009 & -0.008 & -0.052 & -0.099 & -0.165 \\
\hline & {$[0.056]$} & {$[0.051]$} & [0.099] & {$[0.082]$} & {$[0.085]$} & [0.069] & {$[0.145]$} & [0.109] & {$[0.075]$} & {$[0.076]$} & {$[0.130]$} & {$[0.128]$} \\
\hline \multirow[t]{2}{*}{ Electricity, Gas, Transportation and I } & ] $0.142^{* * *}$ & $0.119^{* * *}$ & $0.208^{* *}$ & $-0.164^{* * *}$ & $0.147^{* *}$ & 0.08 & $0.211^{*}$ & $-0.151^{* *}$ & $0.143^{*}$ & $0.155^{* *}$ & 0.049 & $-0.243^{* *}$ \\
\hline & {$[0.047]$} & {$[0.042]$} & {$[0.101]$} & {$[0.062]$} & {$[0.058]$} & {$[0.059]$} & {$[0.123]$} & {$[0.076]$} & {$[0.085]$} & {$[0.060]$} & {$[0.218]$} & {$[0.113]$} \\
\hline \multirow[t]{2}{*}{ Sales and Hotel } & -0.076 & $-0.114^{* *}$ & $-0.257^{* * *}$ & $-0.138^{* * *}$ & -0.094 & $-0.135^{* *}$ & $-0.378^{* * *}$ & $-0.172^{* * *}$ & -0.059 & -0.086 & -0.027 & $-0.095^{* *}$ \\
\hline & {$[0.047]$} & {$[0.046]$} & {$[0.053]$} & {$[0.033]$} & {$[0.067]$} & {$[0.066]$} & {$[0.075]$} & {$[0.046]$} & {$[0.067]$} & {$[0.064]$} & {$[0.076]$} & {$[0.048]$} \\
\hline \multirow[t]{2}{*}{ Finance, Estate, Health and Education } & $0.290^{* * *}$ & $0.112^{* * *}$ & $-0.242^{* * *}$ & $-0.112^{*}$ & $0.328^{* * *}$ & $0.097^{*}$ & $-0.321 * *$ & -0.109 & $0.228^{* * *}$ & $0.130^{* *}$ & -0.063 & -0.103 \\
\hline & {$[0.042]$} & {$[0.041]$} & [0.089] & {$[0.058]$} & {$[0.056]$} & {$[0.058]$} & {$[0.127]$} & {$[0.084]$} & {$[0.064]$} & {$[0.058]$} & [0.121] & {$[0.078]$} \\
\hline \multirow[t]{2}{*}{ Service } & $-0.149 * * *$ & $-0.168^{* * *}$ & $-0.259^{* * *}$ & $-0.131^{* * *}$ & $-0.154^{* *}$ & $-0.219^{* * *}$ & $-0.357 * * *$ & $-0.200 * * *$ & $-0.146^{* *}$ & $-0.114^{*}$ & -0.063 & -0.039 \\
\hline & {$[0.047]$} & {$[0.043]$} & {$[0.056]$} & {$[0.039]$} & {$[0.072]$} & {$[0.061]$} & {$[0.079]$} & {$[0.055]$} & {$[0.064]$} & {$[0.061]$} & [0.080] & {$[0.056]$} \\
\hline \multirow[t]{2}{*}{ Government and Public Administratio } & $0.189 * * *$ & $0.157^{* * *} *$ & -0.094 & -0.224 & $0.170^{* *}$ & 0.105 & $-0.190^{*}$ & -0.308 & $0.228^{* * *}$ & $0.221^{* * *}$ & 0.146 & 0.076 \\
\hline & {$[0.050]$} & {$[0.054]$} & {$[0.083]$} & {$[0.269]$} & {$[0.067]$} & {$[0.076]$} & {$[0.112]$} & {$[0.336]$} & {$[0.078]$} & {$[0.076]$} & {$[0.122]$} & {$[0.473]$} \\
\hline \multirow[t]{2}{*}{ Constant } & -0.057 & $1.438^{* * *}$ & $1.207^{* * *}$ & $1.048^{* * *}$ & -0.214 & $1.340^{* * *}$ & $1.258^{* *}$ & $1.113^{* * *}$ & 0.341 & $1.155^{* * *}$ & 0.939 & $1.084^{* * *}$ \\
\hline & {$[0.294]$} & {$[0.266]$} & {$[0.413]$} & {$[0.185]$} & {$[0.417]$} & {$[0.384]$} & {$[0.579]$} & {$[0.257]$} & {$[0.470]$} & {$[0.401]$} & {$[0.703]$} & {$[0.279]$} \\
\hline
\end{tabular}

Other controls: City Dummies

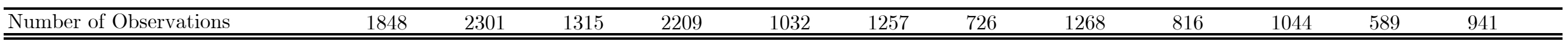

Note: Numbers inside square brackets are standard errors;

$* * *, * *, *$ represent significant at $1 \% .5 \%$ and $10 \%$ level, respectively. 